\title{
Renovating on Unequal Premises: A Normative Framework for a Just Renovation Wave in Swedish Multifamily Housing
}

\author{
Jenny von Platten ${ }^{1,2, *(\mathbb{D}, \text { Karl de Fine Licht }}{ }^{3}$, Mikael Mangold ${ }^{1}$ and Kristina Mjörnell ${ }^{2,4}$ (D) \\ 1 Division of Built Environment, RISE Research Institutes of Sweden, Sven Hultins plats 5, \\ 41258 Gothenburg, Sweden; mikael.mangold@ri.se \\ 2 Department of Building and Environmental Technology, Faculty of Engineering, Lund University, \\ Ole Römers väg 1, Box 118, 22100 Lund, Sweden; kristina.mjornell@ri.se \\ 3 Division of Science, Technology and Society, Chalmers University of Technology, Vera Sandbergs Allé 8, \\ 41296 Gothenburg, Sweden; karl.definelicht@chalmers.se \\ 4 Business and Innovation Area Sustainable Cities and Communities, RISE Research Institutes of Sweden, \\ Sven Hultins plats 5, 41258 Gothenburg, Sweden \\ * Correspondence: jenny.von.platten@ri.se
}

check for updates

Citation: von Platten, J.; de Fine Licht, K.; Mangold, M.; Mjörnell, K. Renovating on Unequal Premises: A Normative Framework for a Just Renovation Wave in Swedish Multifamily Housing. Energies 2021 14, 6054. https://doi.org/10.3390/ en14196054

Academic Editors: Minna SunikkaBlan, Ray Galvin and Ricardo J. Bessa

Received: 22 June 2021

Accepted: 17 September 2021

Published: 23 September 2021

Publisher's Note: MDPI stays neutral with regard to jurisdictional claims in published maps and institutional affiliations.

Copyright: (c) 2021 by the authors. Licensee MDPI, Basel, Switzerland. This article is an open access article distributed under the terms and conditions of the Creative Commons Attribution (CC BY) license (https:// creativecommons.org/licenses/by/ $4.0 /)$
Abstract: While the energy transition of the EU housing stock is now being intensified with the launch of the Renovation Wave, economic inequalities are increasing in many OECD countries, which has effects on housing-related inequalities and the demand of affordable housing. The Renovation Wave is thus an opportunity to improve housing quality for low-income households, but also entails risks for increased rents. In Sweden, the standard of housing is relatively high and energy poverty in multifamily housing is rare, meaning that there are limited social benefits to be achieved from extensive energy retrofitting; moreover, Sweden lacks a social housing sector, which limits protection of the worst-off residents. This paper thus explores whether the limited social benefits of the Renovation Wave weigh up against the risks that it entails for the worst-off in the Swedish context. This is done within a normative framework for just energy transitioning that is developed within the context of the Renovation Wave and increasing economic inequalities, consisting of four ordered principles: (1) The equal treatment principle; (2) The priority principle; (3) The efficiency principle; and (4) The principle of procedural fairness. Analysis showed that to be considered just according to our framework, the Swedish energy transition of housing should, in contradistinction to what is suggested in the Renovation Wave, limit the imposition of extensive energy retrofitting in low-income areas. Finally, having identified a mismatch between the most effective approaches in terms of energy savings and the most acceptable approaches in terms of social justice, we offer policy recommendations on how to bridge this mismatch in a Swedish context.

Keywords: Renovation Wave; social justice; framework for just energy transitioning; affordable housing; energy transition; energy justice

\section{Introduction}

The potentially disastrous effects of climate change forces us to make radical changes in all areas of society when it comes to energy use and carbon emissions. With $40 \%$ of the European Union's (EU) total end use of energy being used in buildings [1], improving the energy efficiency of buildings and housing continues to be an important undertaking in the EU's energy transition. Within the European Green Deal-a growth plan aiming to achieve the UN Sustainable Development Goals by 2030 and union-wide decarbonisation by 2050 [2] - a strategy to trigger a Renovation Wave for Europe was launched in 2020. The main objective of the Renovation Wave is "to at least double the annual energy renovation rate of residential and non-residential buildings by 2030 and to foster deep energy renovations." [3]. These high ambitions for increased investments in the building stock imply that the Renovation Wave marks a new era in the energy transition of housing all across the EU, which will affect people from all strands of society. 
Assuming that these comprehensive measures are inevitable in order to minimise the negative effects of climate change, the question of how to implement such measures poses great challenges from a social justice perspective. The unprecedented nature of energy transitions makes every new case a case for scrutiny to ensure a development that is both environmentally and socially sustainable; but apart from energy transitions' inherent novelty in terms of technology, practices, and environmental and social consequences, they also tend to occur in unprecedented times [4]. The current situation of climate urgency is indeed unmatched in history, and among the forerunners of sustainable energy transitions, including many OECD countries in general and Nordic countries in particular [5], economic inequality has been on the uprise since the 1980s [6]. It is thus of high relevance to ensure that the Renovation Wave contributes to reduced—not increased—inequalities when rolling over the European housing stock. While improving the energy performance of housing in many EU member states enables a reduction of issues such as energy poverty and vulnerability [7], imposing energy retrofits in low-income housing can also have negative effects for residents such as increased rents, displacement or fear of displacement, and tenant-landlord conflicts [8], and in the long run undermine the availability of affordable housing if such availability is not strongly protected [9]. However, despite an abundance of energy justice research on the interconnectivity between residents and buildings' energy use, little has been said about how energy transitions of housing stocks affect residents on a more general level in an era of increasing economic inequalities [10]; this is of particular interest as energy policy often focuses on the worst energy-performing buildings, which tend to be located in segregated and economically disadvantaged areas [11,12]. Given the high, and most likely costly, ambitions of the Renovation Wave in combination with increasing vulnerability among the worst-off due to the rise of economic inequalities, there is a need to scrutinise what structural injustices this strong focus on worst-performing buildings could have for worst-off residents.

In this paper, we are going to give a first outline of the questions of social justice that arise when going through an energy transition in residential housing, and we will also give some preliminary answers and a framework on how to deal with these issues. This will be achieved by combining normative theories on social justice with different overarching approaches for reduced energy use in the housing stock. Using relevant normative considerations and theories hopefully brings more depth and clarity to these issues in the policy debate and can facilitate the design of effective and just measures in member states' implementation of energy policy in general and the Renovation Wave in particular. In order to make the discussion and recommendations even more tangible, this paper is limited to the Swedish multifamily housing stock as a case study. Sweden is particularly interesting as the occurrence of energy poverty is low and the housing standard is relatively high in a European context; this means that the social benefits of deep energy retrofitting in terms of reduced energy costs and improved thermal comfort are lower than in other EU member states, and it is thus of high relevance to carefully analyse the risks and injustices that the Renovation Wave might entail in order to ensure that the risks do not outweigh the opportunities. More so, Sweden lacks a social housing sector, which limits the protection of economically disadvantaged residents, and residents' vulnerability on the housing market has been increasing along with the growing economic inequalities that have increased at a higher rate in Sweden than in any other OECD country since the 1980s. Sweden thus presents a clear case of the increasingly ubiquitous situation where extensive energy retrofitting is carried out on a pressured and progressively unequal housing market.

\section{Research Approach}

This paper is based on normative analysis and argumentation where a set of normative theories are applied to the Swedish context of energy transitioning and the Renovation Wave. The research methodology is thus rather a research approach, where the different chapters of the paper constitute different pieces of the puzzle in the normative argumentation. The purpose of the different chapters and the structure of the paper are thus as 
follows. Section 2 outlines more details regarding the Renovation Wave and describes the Swedish context of increased economic inequalities and the housing market on which the Renovation Wave will be rolled out. This chapter thus defines the specific context. Section 3 then describes overarching approaches for reduced energy use in the housing stock and evaluates their respective feasibility and energy savings potential in the Swedish context. This chapter consequently offers different alternatives to energy use reduction in the housing stock that later can be evaluated and compared from a normative standpoint. Based on normative theories relevant for the distribution of benefits and burdens, Section 4 then develops a preliminary framework for how an energy transition of the housing stock in general, and the Renovation Wave in particular, can be carried out in a manner that is considered socially just within the previously described context. This chapter thus provides a normative foundation from which an argumentation can be built. In Section 5 , the preliminary framework for a just energy transition of the housing stock developed in Section 4 is applied to the different approaches described in Section 3 in light of the context described in Section 2, with the aim to analyse which approaches are considered more and less just. Based on the normative analysis and argumentation in Section 5, Section 6 offers more concrete policy recommendations for the Swedish context. The paper concludes with a summary of the main findings in Section 7. A flowchart of the research approach can be seen in Figure 1, showing the conceptual (rather than chronological) research approach in this paper.

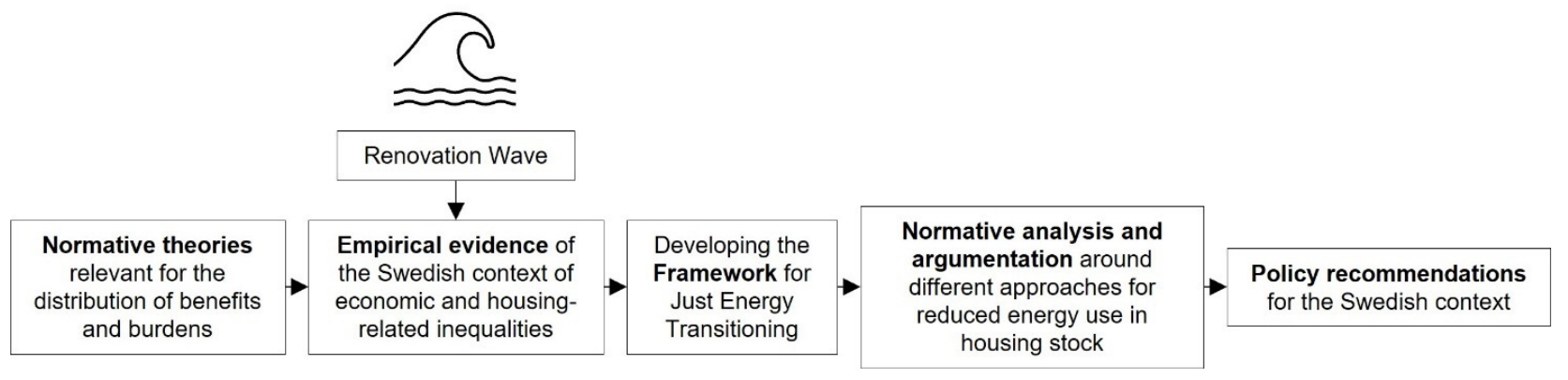

Figure 1. Flowchart of the conceptual research approach.

\section{The Renovation Wave in a Context of Increasing Economic Inequality}

The building stock is a high priority for improved energy efficiency in the EU [13]. Central objectives in the EU for 2030 are to improve overall energy efficiency by $32.5 \%$ (compared to projections of the expected energy use in 2030) [14] and to reduce greenhouse gas emissions by 55\% (compared to 1990 levels) [15]. Directive EU/2018/844 on the energy performance of buildings guides member states in how to achieve these goals through deep energy retrofitting of the existing building stock, primarily focusing on worst-performing buildings, and a near zero-energy standard for new construction.

In 2020, the EU launched the Renovation Wave. Given that energy efficiency measures more often than not are carried out in conjunction with general refurbishment, the Renovation Wave is a strategy for improving the energy performance of buildings through an increased renovation rate. It is launched as a part of the European Green Deal, which contains a set of policy initiatives with the overarching goal to make Europe climate neutral by 2050. The Renovation Wave contributes with guidelines and regulations for achieving this overarching goal in the building sector and focuses on action in three main areas: (i) decarbonisation of heating and cooling; (ii) tackling energy poverty and worst-performing buildings; and (iii) renovation of public buildings [3]. Apart from increasing the rate of renovation, the aim is also to stimulate deeper renovations, i.e., achieving greater energy savings in each renovation project. This means that the EU commission is mainly seeking an increase in extensive and comprehensive renovations that inevitably will be costly. At the same time, there are prominent goals considering the affordability of energy-efficient and sustainable housing to allow all groups of society to have access to 
high-quality accommodation. Although a number of different funding solutions are to be established, the access to and distribution of funds will be managed at the member-state level [3], meaning that there are no guarantees that funding will be earmarked for affordable housing or low-income households [16]. More so, the conflict between expensive energy renovations and housing affordability is likely to remain as minimum requirements for energy performance are expected [17], meaning that investments not covered by energy savings could be imposed [18].

Sweden tends to have more ambitious energy and climate policies than the EU in general, and apart from complying with EU regulations and targets, Sweden has a national target to reduce the energy intensity in relation to GDP with 50\% from 2005 to 2030 [19]. In the housing stock, this target can be interpreted as improving buildings' energy performance (energy use per square meter and year, $\mathrm{kWh} /\left(\mathrm{m}^{2} \times\right.$ year)) by $50 \%$ over the same period of time. Decarbonisation of the Swedish housing stock has progressed successfully since the oil crises in the 1970s [20], and the housing stock is today highly decarbonised with district heating dominating in multifamily buildings [21] and heat pumps rapidly increasing in single-family houses [22]. Consequently, having come far on the journey towards decarbonisation, much attention is now being directed towards improved energy performance in the housing stock in general, and in the multifamily housing stock in particular. Energy use for heating and domestic hot water in multifamily buildings accounts for around one third of such energy needs in residential and commercial buildings, and approximately 7\% of the total end use of energy in Sweden [22]. Two of the main barriers to increased energy performance in the Swedish multifamily housing stock is a lack of profitability in energy retrofitting [23] as well as difficulties to assess profitability [24]; thus, although energy performance has continued to improve since the 1970s, and although the energy performance of buildings in Sweden is relatively high compared to other EU member states, there is still great potential to reduce the energy use at the building stock level. It can thus be expected that the Renovation Wave will spur a lot of activity in the Swedish multifamily housing stock, and that both renovation rate and depth will increase. There is, however, a concern among Swedish housing companies that the Renovation Wave will impose unprofitable energy retrofits [18].

\subsection{The Social Aspects of the Renovation Wave}

A strong focus on worst-performing buildings is argued for in the Renovation Wave as well as in Swedish energy policy. Within the EU, this focus is strongly connected to the widespread issue of energy poverty. Energy poverty can be defined as a state in which households struggle to keep their home adequately warm either due to financial reasons or owing to their geographic [25], social [26], or national-specific context [27]. Households suffering from energy poverty are often, but not always, in a combined situation of low income, low energy performance of the dwelling, and high energy prices [28]. Improved energy performance can thus be one way to reduce a household's vulnerability to energy poverty and has been adapted as the main remedy for energy poverty in the Renovation Wave. In Sweden, there is however a very low prevalence of energy poverty [29]. This is partly due to the relatively high energy performance of buildings in combination with relatively low energy prices and a strong social support system, but also the fact that heating costs are included in the rent in the vast majority of multifamily housing in Sweden, a system often called "warm rent" [30]. Unlike in EU policy, where there is a clear social incentive to focus on worst-performing buildings, the focus on worst-performing buildings in Sweden lacks such concerns and is rather driven by maximising cost-effectiveness in energy retrofitting.

Although national and international climate and energy targets are significant drivers for improved energy performance of buildings, there are also numerous benefits to be harvested for residents and property owners from such measures. Among these are reduced energy costs and improved indoor climate. A household does not have to be defined as energy poor in order to suffer from high energy costs or a poor indoor climate; effects of 
inadequate heating, and/or draught due to air leakage or poor insulation in the building envelope, can be poor thermal comfort with high moisture loads causing condensation and even mould growth [31]. Such conditions can have negative effects on health and risk leading to illness or disease among residents [32]. Severe conditions of this sort constitute a relatively small issue in Sweden owing to a good housing standard and comparatively progressive regulation concerning indoor climate [33], but it constitutes a widespread problem in many EU member states [34].

There can thus evidently be many social benefits from the Renovation Wave and improved energy performance of housing, but the rather aggressive roll-out of a policyprogram of this sort that imposes extensive and expensive retrofits can also entail risks for vulnerable resident groups. In Sweden, where the expected social benefits of energy retrofitting arguably are not as high as in other EU member states, it is thus of high relevance to carefully analyse the risks and injustices that the Renovation Wave might entail in order to ensure that the risks do not outweigh the opportunities. As the risks associated with the Renovation Wave are closely linked to the situation of economic inequality and housing segregation, the following section will describe the Swedish context of how the economic development over the past decades has led to a deeply unequal housing market.

\subsection{Economic Inequality, Housing, and the Renovation Wave}

Caused by an uprise of neoliberal ideas and tax reforms, economic inequalities have increased in many OECD countries since the 1980s [35]. Among OECD countries, Sweden is the country that has experienced the most rapid increase in income inequality, although inequality levels in Sweden remain comparatively low [36]. Nevertheless, this development has led to increased residential segregation [37] and increased vulnerability among households that request access to affordable housing.

Sweden lacks a formalised provision of social housing, but public municipal housing companies have traditionally owned a significant share of the rental housing stock [38], and rental housing is more common in Sweden (36.4\%) than in most other EU member states (30.2\% on average) [39]. For most of the 20th century (1940-1990), the objective of municipal housing companies was to provide "housing for all" [40], and with a strong focus on affordability and social sustainability municipal housing companies offered a feasible alternative to pure social housing. This period of time was characterised by strong housing regulations and heavily subsidised housing policy that aimed to relieve the pressing housing shortage and the generally low housing standard that prevailed [41]. In 1964, it was decided that one million dwellings were to be constructed during 1965-1975, which was carried out and achieved in the so called Million Homes Programme [42]. About one third of the dwellings were constructed as single-family houses whereas the rest were constructed in multifamily buildings to a large extent situated on the outskirts of cities around Sweden. The completion of the Million Homes Programme provided an unprecedented opportunity for many households to access a modern dwelling.

However, deregulation of the housing market in the early 1990s ended a long period of socially oriented housing policy [41]. Apart from subsidies and favourable loans being cut off, tenant associations' leverage was also reduced [40]. As municipal housing companies were slowly forced into competing with private housing companies, parts of municipal housing stocks were sold to private housing companies or converted into tenant-owner cooperatives (similar to housing cooperatives), and the increased competition undermined municipal housing companies' social commitment e.g., through introduction of minimum income requirements for leases [43].

The combination of reduced social commitment in housing supply, increased housing shortage owing to under-production of new buildings, and increasing economic inequalities-now also spurred by the 1990s financial crisis-set the stage for an increasingly precarious housing market that is very different from the one that existed at the end of the Million Homes Programme. At the end of the 1990s, Sweden's largest cities had the highest levels of ethnic residential segregation among OECD countries [44] and 
residential segregation by income was higher than ever before in Sweden [37]. Yet, little political action towards increased supply of affordable housing has been taken. In 2000, a law stating that municipal housing companies have a responsibility to provide housing for all inhabitants in the municipality was enforced [45], which somewhat ensured affordable housing supply. However, municipalities are not obliged to have municipal housing companies, and the municipal housing companies are restricted by the 2011 law about municipal housing companies [46] that regulates the fiscal transfers over longer time periods and between the municipality and the municipal housing companies, undermining long-term perspectives in investments and forcing them to sell parts of their housing stock to finance renovations $[45,46]$. Needless to say, this further constrained municipal housing companies' ability to provide affordable housing and to constitute a feasible substitute to social housing [47].

Today, access to housing is increasingly dependent on economic resources [47], and the housing system has become a reproducer of economic inequalities [48]. Many of the suburban areas of multifamily buildings from the Million Homes Programme are economically and ethnically segregated areas with increasing over-crowdedness, especially on the outskirts of larger cities [49]. Several market mechanisms are limiting the construction of affordable housing [50]; this in combination with municipal housing companies being forced to sell parts of their housing stocks to comply with the law [46] has caused the supply of affordable housing to fall short of the demand [51]. As a consequence, the second- and third-hand rental markets have grown, and legal as well as illegal subletting are becoming more frequent; of course, the lack of affordable housing, and to some extent the lack of housing in general, is forcing rents on the illegal second- and third-hand markets above the regulated levels [51,52]. Moreover, increased globalisation and financialisaton of housing [53] have attracted international private equity firms to invest in housing with rent levels below market levels, i.e., affordable housing, and carry out measures that allow them to rapidly increase the rents [54]. In Sweden, such investments have mainly occurred in the suburban areas of multifamily buildings constructed during the Million Homes Programme [55,56], where vulnerability to increased rents is high. Yet, Swedish rent regulation states that apart from the collective negotiations between landlords and tenants' associations that determine yearly rent increases, rents can only be increased after specified apartment qualities have been upgraded [57]; this is how renovations have come to constitute the motor in strategies for possible rent increases.

\section{Retrofitting on an Unequal and Pressured Housing Market}

Rent setting in general and rent increases in conjunction with renovations in particular are rather strictly regulated in Sweden compared to in other EU member states. General rent levels are collectively negotiated between landlords and tenants' associations, and while renovation measures are legally a matter between landlords and tenants only, rent increases after renovation are negotiated with tenants' associations. In every renovation project, housing companies thus negotiate with the tenants regarding the measures included in the renovation project, and in larger renovation projects, tenants' associations are often contacted by the landlord. Measures that in some way increase the standard, quality, or utility of the apartment, so called quality-upgrading measures, allow for rent increases whereas measures that merely aim to restore the apartment, or measures for general refurbishment of common building services, do not [57]. For example, installation of a modern kitchen (with, e.g., a built-in microwave) or bathroom (with an electric towel dryer) would, e.g., count as quality-upgrading measures, whereas improved energy performance of the building or restoration of damaged components/interior usually would not. Owing to how the Swedish rent regulation is constructed, many private housing companies systematically carry out quality-upgrading renovations to increase rents in their housing stock [58]. As renovation projects often contain a set of different retrofitting measures, it is not uncommon that energy efficiency measures are conducted alongside qualityupgrading measures. 
The fact that energy efficiency measures usually do not enable rent increases suggests that the Renovation Wave with its strong focus on buildings' energy performance should not constitute a risk for increased rents. Although this is theoretically true, many factors add up to create a situation where the Renovation Wave in practice-through inclusion of quality-upgrading measures in energy retrofitting projects-could indeed become a driver for increased rents and inequalities on the housing market in general and in low-income areas in particular. First, there is a pressure among housing companies to increase rents due to the general housing shortage in Sweden, which makes it possible to significantly increase rents and still find tenants [58]. It has been suggested that during a housing shortage, the Swedish rent regulation system creates economic incentives for quality-upgrading beyond what would be feasible in a market system; apart from constituting a suboptimal use of financial and ecological resources, this risks leading to increased gentrification [58]. More so, private housing companies' increased acquisition of affordable housing creates a pressure to close the gap between affordable housing and market rent levels [58].

Second, in the general Swedish discourse (public and policy oriented), it is in particular multifamily buildings from the Million Homes Programme that have been pointed out as the worst-performing buildings in need of energy retrofitting as well as general refurbishment [59]. As the buildings constructed during the Million Homes Programme are reaching their service life of 50 years, there is indeed a need for general refurbishment which can be combined with energy-efficiency measures [24]. However, given the socioeconomic vulnerability in many of these areas, it has been argued that renovations should be carried out in a gentle manner with as little measures as possible to ensure an adequate housing standard out of consideration for the tenants [60], or by offering tenants different renovation options [61] where the least expensive option preferably entails no rent increase at all [62]. Such careful and considerate renovation methods are, however, not in line with the high energy efficiency ambitions of the Renovation Wave, as increased social consideration often compromises energy savings [60,61], and vice versa [63]. Looking beyond the Million Homes Programme, the general trend of energy performance being higher in higher-income areas remains [11]; thus, the worst-performing buildings, which are prioritised in the Renovation Wave, are often found in low-income areas. It is thus a common notion in the public debate, supported by the focus on worst-performing buildings in the Renovation Wave, that the primary need for extensive energy retrofitting is found in low-income areas in general and in housing from the Million Homes Programme in particular.

Third, as profitability is often difficult to achieve in deep energy retrofitting projects [60], it has been documented how landlords include quality-upgrading measures in their energy retrofits to enable rent increases and thus improve the cost-effectiveness of the retrofitting project $[60,61]$. There are of course many factors that influence the profitability in energy retrofitting projects, such as the discount rate, reduced maintenance costs, and other assumptions about e.g., future energy prices and rent levels; but increasing the rent after renovation is one way to improve profitability in renovation projects and can also be a means to quickly increase the property taxation value. In addition, the long pay-back times that extensive energy-efficiency measures such as additional façade insulation can entail requires a long-term perspective that many profit-driven housing companies lack [60], especially on an increasingly financialised housing market. More so, as improved energy performance does not suffice for rent increases, landlords face the risk of actually having to lower their rents due to reduced energy costs [64], which again increases the pressure to find other means to improve profitability, such as increased rents. The fact that the Renovation Wave strongly pushes for deep energy retrofitting will contribute to increased tension between energy savings and profitability, which in turn will increase the pressure among housing companies in Sweden to include quality-upgrading measures in their energy retrofitting projects.

Finally, some landlords seek to increase profitability and property value by replacing residents of lower socioeconomic status with residents of higher socioeconomic status [65]. 
Speculation and gentrification are known to push up rents, and displacement of residents is sometimes achieved through the phenomena known as "renoviction" [66] or "green gentrification" [67,68]; the latter refers to cases when landlords hide their underlying motives of tenant replacement behind a façade of ecological sustainability objectives. However, perhaps more common is the process of exclusionary displacement [69], where quality upgrading of apartments and consequential rent increase is carried out after a tenant has voluntarily moved, meaning that the next tenant to move in is likely to have a higher socioeconomic status than the tenant that moved out. While such exclusionary displacement does not force residents away, it still contributes to a process of gentrification and a more long-term undermining of affordable housing availability [61]. Although it remains unknown to what extent the Renovation Wave will contribute to these types of tenant displacing phenomena, it will nonetheless offer a "green" façade that risk being used for socially unsustainable purposes.

In summary, although it is not custom to increase rents based on energy efficiency measures, several interacting factors contribute to a general pressure among landlords to include other measures that enable rent increases in energy retrofitting projects, and in low-income areas in particular, such as:

- A general housing shortage (mainly of affordable housing) in Sweden, which enables housing companies to renovate to increase rents to a greater extent than if there were no such shortage;

- Challenges to achieve profitability in extensive energy retrofitting projects;

- Loopholes in the rent-setting regulation, which allow for rent increases for specific quality-upgrading measures;

- A strong focus on multifamily housing in energy policy, and on areas from the Million Homes Programme in particular;

- Focus on worst-performing buildings in the Renovation Wave where low-income residents are overrepresented;

- Private companies with explicit business models of acquiring, renovating, and subsequently selling multifamily buildings in low-income areas.

Apart from the multiple factors that interact to create a pressure to increase rents under the Renovation Wave, retrofitting does not only have economic implications for tenants but also include elements of negotiation and power-relations between tenants (partly through tenants' associations) and landlords. In local and appeal court decisions on renovation measures, it has been found that more than $90 \%$ of cases are ruled in the landlord's favour [70]. Studies have shown frequent negative emotions among tenants in renovation projects in general [71], and energy retrofitting in particular [72]. Inevitably, economic inequalities and residential segregation have implications for these experiences and processes too. The general housing segmentation, causing tenant-owned housing to dominate among high-income earners, causes the most well-off to have maximum influence on and control over renovation processes in their home. Among well-off tenants, who assumingly can exert the maximum influence possible on renovation processes in rental housing, it has been shown that influence over the renovation process is possible yet limited [73]. This suggests, and it has been shown [62,74], that the worst-off have limited possibilities to influence renovation processes, especially considering the increase in illegal subletting, which is likely to significantly compromise tenants' exertion of power towards landlords.

With a weakened position of the Swedish municipal housing companies, and an increasing prevalence of private housing companies with short-term perspectives on management and profits in low-income areas, we find that the Renovation Wave might put increased pressure for rent increases on already pressured parts of the housing stock as illustrated in Figure 2. Although companies act very differently and it is impossible to predict what the outcome will be from each renovation case, there are multiple factors that risk leading to increased inequalities in the housing stock and society as a whole. In light of the increasing economic inequalities in Sweden, and the general lack of affordable housing, 
this paper ultimately asks and tries to answer the question: What would it mean for the Renovation Wave to be just in a Swedish context, and can we achieve a just energy transition by putting the worst-performing buildings at the frontline, which is now the case?

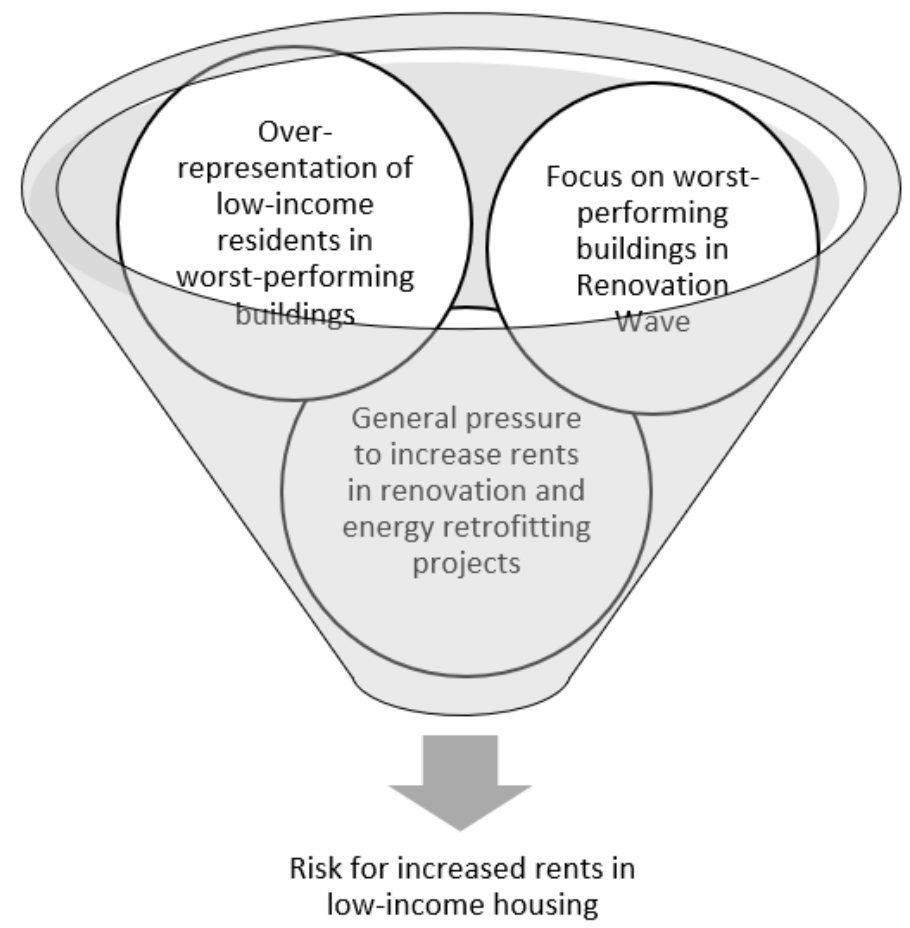

Figure 2. Some of the main factors that together create a risk for increased rents in low-income housing in particular in the Renovation Wave.

\section{Ways to Reduce Energy Use in the Housing Stock}

To acknowledge that the Renovation Wave is not the only solution to reduce energy use in the housing stock but that there are innumerable ways to improve energy efficiency and reduce energy demand, this section will outline the different main approaches. The focus here will be on the overarching housing stock level, concerning the buildings and the residents' interactions with the buildings only. Simply put, the total yearly energy use in a specific housing stock can be described by Equation (1), where the total energy use is the total sum of the buildings' energy use per square meter (energy performance (EP), $\mathrm{kWh} /\left(\mathrm{m}^{2} \times\right.$ year $\left.)\right)$ multiplied with the building area $\left(\mathrm{m}^{2}\right)$.

$$
\text { Yearly energy use in housing stock }=\Sigma(\mathrm{EP} \times \mathrm{A})
$$

In order to reduce the yearly energy use in the housing stock, the two main approaches are thus (i) to reduce the energy use per square meter, i.e., improve the energy performance of buildings; and (ii) to reduce the needed area in a certain housing stock. The following sections will cover how these different approaches can be realised and detail the proved and/or predicted feasibility of the different measures in terms of energy savings, cost effectiveness, and general acceptance and recognition. A building's energy performance is here defined as a building's yearly energy use for heating, domestic hot water, and electricity use for common services. Households' electricity use for appliances is thus excluded, meaning that the focus will be on energy use dictated by the building's construction and installations (and the residents' interaction with these). In doing so, the focal point becomes the actual buildings, rather than household appliances situated in them, which is in line with international targets and strategies for reduced energy use at the housing stock level [13]. 


\subsection{Improving Buildings' Energy Performance}

Improved energy performance of buildings has been, and continues to be, the central strategy for reduced energy use in the housing stock. It is embedded in the core of our understanding of "energy efficiency" to deliver the same service at a reduced energy use; the service in this case being a fixed area of heated and ventilated space. Returning to Equation (1), efforts to reduce energy use in the housing stock are thus almost exclusively directed towards improved energy performance (EP) rather than reduced area (A). As the energy performance of a building is affected by both the technical efficiency of the building's structure and installations as well as by the residents' energy-related behaviour, ways to improve technical efficiency and ways to improve energy-efficient behaviour will here be described separately.

\subsubsection{Improved Technical Performance}

The Renovation Wave mainly focuses on renovations that improve the technical efficiency of buildings. For a building to operate in a way that ensures comfort and a good indoor environment, energy is primarily needed for heating, domestic hot water, and ventilation. To improve the technical efficiency of a building, these energy demands can either be reduced through energy retrofitting, or the energy supply to meet these demands can be made more efficient by installing more efficient energy technologies. Reduced energy demand through energy retrofitting is achieved by reducing the transmission of heat from the building. This can be done with renovation measures on the building envelope, such as adding additional insulation to reduce transmission; assure airtightness of the building envelope; replacing windows with alternatives with lower transmission; adding insulation to roofs, attics, or water pipes; etc. Installing heat exchange between exhaust air and supply air in the ventilation also reduces the building's heating demand. Reduced energy use for heating can also be achieved without reducing the building's heating demand by instead replacing the current heating system with a more efficient system, e.g., substitute an oil-fired boiler with a heat pump, so that less energy is needed to produce the same amount of heat. Similar to such technological substitution, continuous technological improvements make upgrading of installed appliances such as heat and circulation pumps to newer and more efficient alternatives a feasible option to improve energy performance [75].

Although there are many well-tested and developed methods for energy-saving renovations, policy and financial support have remained limited, which in combination with high upfront investment costs and long pay-back times have kept the renovation rates low in Sweden [76]. Cost-effectiveness tends to be the highest in worst-performing buildings as a low energy performance often indicates that there are "low hanging fruit" in terms of improved energy performance, which is why worst-performing buildings are specifically targeted in the Renovation Wave as well as in Swedish energy policy. The existing barriers and the slow renovation rate are some of the reasons to why the Renovation Wave is now being initiated, and as the objective of this policy initiative is to remove at least some of the barriers and offer more financial support, a positive development in the general feasibility of energy-saving renovations is to be expected. In terms of technological substitution and installation of more efficient versions of already installed technologies, the barriers have in general been lower, partly owing to lower upfront costs [75].

Policies for reduced energy use in the housing stock are mainly focused on improved technical energy efficiency of buildings in line with the above-described measures, as confirmed by the Renovation Wave. Many policymakers, researchers, and practitioners have much faith in the potency of improved technical energy efficiency in conjunction with general refurbishment. Although it is technically possible to significantly reduce a building's energy performance through technical energy efficiency measures, the issue of profitability and cost-effectiveness remains a challenge in energy retrofitting projects for many housing companies. More so, it is important to not only focus on the building's energy performance, but to also consider the embodied energy, climate, and environmental impact that renovation projects and measures entail [77]. Finding measures that reduce 
the building's energy use at the minimum "cost" in terms of energy use and emissions for construction and materials is key for sustainable energy retrofitting.

\subsubsection{More Energy-Efficient Behaviour}

Beyond the efficiency of a building's structure and installations, residents' interactions with the building have implications for the amount of energy needed to operate the building, and residents' energy-related behaviour can both increase and decrease the building's energy performance. Residents' impact on a building's energy performance mainly depends on their energy-related behaviour in connection to heating and domestic hot water use [78]. In terms of heating, residents' impact mainly concerns choice of indoor temperature and manually induced ventilation by opening windows [78]. However, the energy performance of the building affects the potency of behavioural change to impact the energy use. For example, changes in indoor temperature have a lower impact on heating demand in well-insulated buildings than in less-insulated buildings. This is, however, not the case regarding energy use for domestic hot water. Domestic hot water use varies greatly among different households and depends both on behavioural patterns and household size [79].

To reduce buildings' energy use through behavioural changes, residents must have some sort of incentive to change their behaviour. This could, e.g., either be a will to do good for the environment or purely economic incentives. Economic incentives only exist if the residents' energy use for heating and/or domestic hot water is measured and billed at the household level, which is the case in most EU member states. However, in Sweden, energy use for heating and hot water was formerly rarely measured and billed individually for households. Heating and water expenses are instead included as a fixed component in the monthly rent, which is then often referred to as "warm rent". This system leaves residents with no economic incentives to change their energy-related behaviour (regarding heating and domestic hot water) as it would not affect their arguably invisible energy costs. This gives rise to an issue of split incentives between the residents and the property owner [80], and as a remedy, directive 2012/27 / EU on energy efficiency requires energy for heating and hot water to be measured and billed for individual households in order to incentivise more energy-efficient behaviour. Although Sweden has tried to argue for the benefits of warm rent, among which are the fact that it gives landlords economic incentives to invest in energy efficiency, a compromise with the EU commission was reached in 2019 requiring that energy for heating should be individually metered and billed in worstperforming multifamily buildings [81]. It was also decided that energy for domestic hot water should be individually metered and billed in new construction and deeply renovated buildings [82].

The potential for reduced energy use through behavioural change has been estimated at $10-25 \%$ [83]. Regarding energy use for domestic hot water, individualisation of metering and billing has shown promising yet varying results [84]; however, it has also been found that low-income households experience significant cost increases from this measure as household size, i.e., the number of residents in the household that use hot water for e.g., showering, tends to be greater among low-income earners [85]. More so, increased time at home due to e.g., unemployment or illness will further increase water use among the worst-off [85]. Thus, although low-income households might significantly reduce their water consumption after implementation of individual metering and billing, the fact that they still consume more water than the average household would cause increased costs regardless of water-saving behaviour [85]. Overall, as the implementation of individual metering and billing of energy for heating and domestic hot water remains low in Sweden, there are many barriers for achieving energy savings through behavioural changes as there most often are split incentives between residents and property owners, and as potential energy cost reductions are relatively low owing to low energy prices. The barriers for energy savings through behavioural change in Sweden has thus been estimated as relatively high [75]. 


\subsection{Reducing per Capita Living Space}

As was shown in Equation (1), another way to reduce the total energy use in the housing stock is to limit the total building area, or to use it more efficiently. For many decades, improvements in buildings' energy performance have to some extent been offset by increased living space per person [86], which can be understood as a rebound effect due to the improved efficiency [87]. Consequently, there are reasons to not only focus on improving energy performance but to also try to utilise the area in the existing building stock more efficiently to limit the living space per capita and reduce the need for new building construction [88]. Yet, reducing living space per capita is rarely recognised as a means to reduce energy use for housing, although implications of space utilisation on energy use is gaining more and more attention in the commercial sector such as in office buildings and hotels [89]. One of the reasons as to why energy performance of housing is being politically advocated while little policy is concerned with housing size is the hesitancy to decrease overall production. Although over-consumption of products, recourses, and energy is the root to many contemporary challenges, our economic system and social norms prefer green consumption over reduced consumption. Thus, it is usually more politically feasible to promote "greening", i.e., improved energy performance, over reduced consumption, i.e., reduced dwelling size.

The average living space per capita in the Swedish housing stock is among the highest in the EU [90]. However, distribution of area in the Swedish housing stock is far from even as residential density varies greatly between different demographic and socioeconomic groups [11], as can be seen in Figure 3, and differences between different income groups are increasing [11]; the current trend is that low-income households are living more and more densely, with over-crowdedness becoming increasingly prevalent [91], while there is little to no change in the average living space per capita in higher income segments [11]. As the per capita living space linearly affects the per capita energy use for housing (see Figure 3), the increasing gap between low-income and high-income households' energy use can be understood in the light of the increasing economic inequalities that increasingly are affecting access to housing. Although over-crowdedness is highly recognised as a societal problem with potential negative effects on health and well-being, excess of living space as a driver for energy use in housing is overlooked in the general discourse, meaning that there is little effort being put into limiting excessive living space per capita. Yet, Figure 3 shows that the per capita energy use is more closely correlated to per capita area use than to buildings' energy performance, suggesting that reduced living space per capita can be an effective means to reduce per capita energy use in the housing stock. Figure 3 shows multifamily buildings only and does therefore not include vacation dwellings; the inclusion of vacation dwellings would further amplify the differences between income deciles.

Looking at building stock level, a higher residential density leads to many benefits in terms of resource efficiency, including a lower energy use, as it contributes to an economy of scale where the energy needed for each individual to heat, ventilate air, and use hot water for cooking and washing will be reduced [92]. The fact that household size is decreasing, causing the average living space per capita to increase, in many parts of the world has been argued as a great challenge for reduced resource use and carbon footprint per capita [93].

Finally, Table 1 shows a synthesis of the estimated energy-saving potential, barriers, and political/general recognition of the three main approaches for reduced energy use in the housing stock that were described in this chapter. 


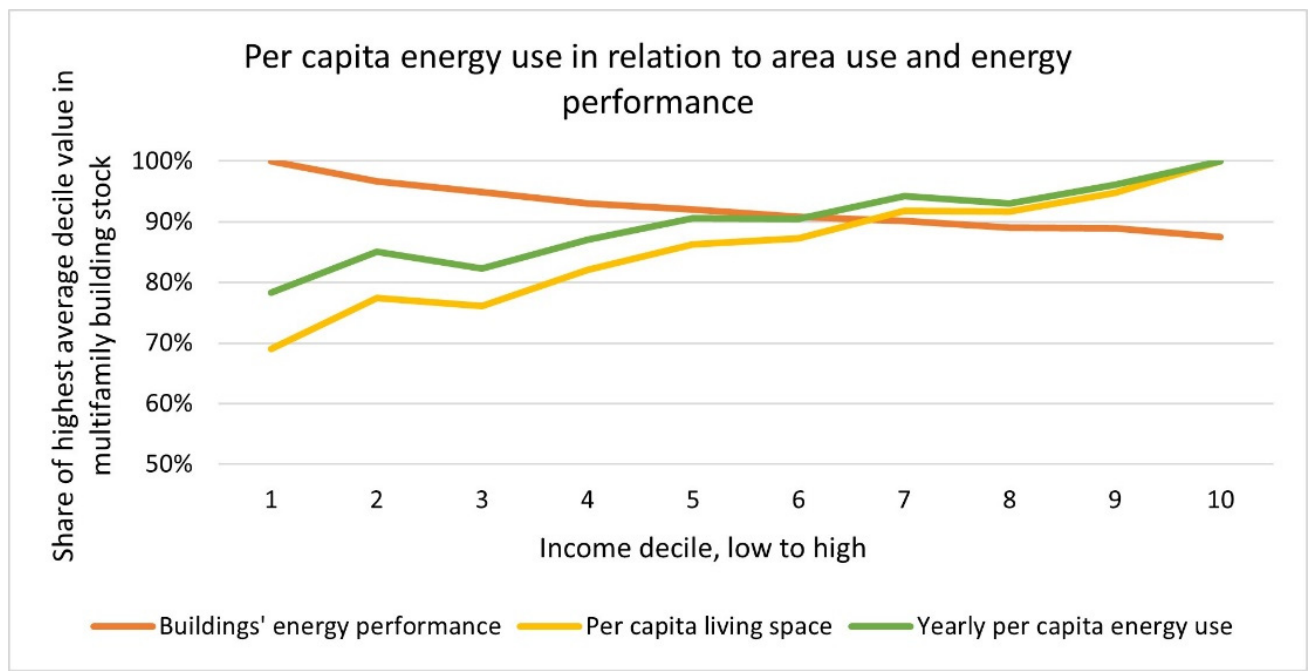

Figure 3. Average values of buildings' energy performance (red), per capita living space (yellow), and yearly per capita energy use for housing (excluding household electricity use) (green) for different income deciles. Data are for multifamily buildings only and have been processed as described by von Platten et al. [11].

Table 1. Synthesis of the potential, barriers, and recognition of the three main ways towards reduced energy use in the housing stock.

\begin{tabular}{|c|c|c|c|c|}
\hline Approach & $\begin{array}{c}\text { Energy Savings } \\
\text { Potential }\end{array}$ & $\begin{array}{l}\text { Part of Housing Stock } \\
\text { with Largest Potential } \\
\text { (Maximisation Strategy) }\end{array}$ & Barriers & $\begin{array}{c}\text { Recognition } \\
\text { (Housing Stock Level) }\end{array}$ \\
\hline $\begin{array}{l}\text { Improved technical } \\
\text { performance } \\
\text { (Renovation Wave) }\end{array}$ & High potential & $\begin{array}{l}\text { Greater potential and } \\
\text { higher cost-effectiveness } \\
\text { in buildings with low } \\
\text { energy performance }\end{array}$ & $\begin{array}{l}\text { Low energy prices } \\
\text { mean low profitability } \\
\text { and cost-effectiveness } \\
\text { of investments in } \\
\text { energy efficiency }\end{array}$ & $\begin{array}{l}\text { Highly recognised } \\
\text { and endorsed }\end{array}$ \\
\hline Behavioural changes & Relatively low potential & $\begin{array}{c}\text { Slightly greater potential } \\
\text { in buildings with low } \\
\text { energy performance }\end{array}$ & $\begin{array}{c}\text { Split incentives } \\
\text { between tenants and } \\
\text { property owners, } \\
\text { relatively } \\
\text { low-cost savings }\end{array}$ & $\begin{array}{l}\text { Recognised but not } \\
\text { highly endorsed }\end{array}$ \\
\hline $\begin{array}{l}\text { More efficient use of } \\
\text { living space }\end{array}$ & $\begin{array}{l}\text { Can reduce demand for } \\
\text { new construction }\end{array}$ & $\begin{array}{l}\text { Primarily affluent parts } \\
\text { of housing stock where } \\
\text { living space per capita } \\
\text { is large }\end{array}$ & $\begin{array}{l}\text { Societal structures in } \\
\text { place that support } \\
\text { unequal living } \\
\text { space accessibility }\end{array}$ & Unrecognised \\
\hline
\end{tabular}

\section{A Preliminary Framework for Just Energy Transitioning}

There are a wide range of competing fundamental normative theories, considerations, approaches, and frameworks in the social justice literature relevant for the Renovation Wave (see e.g., [94]). Famously, Sovacool and Dworkin [94] outlaid a framework for just energy transitioning where they describe a wide range of fundamental normative principles and then try to use these to produce a practical decision-making tool for decision-makers. What we are going to do here is something similar, partly building on this framework, but tailored for the Renovation Wave within a context of increasing housing-related and economic inequalities. To do this, we will add some fundamental normative theories regarding distribution and adjust the focus such that the emphasis is on our particular case. In the case of the Renovation Wave, everyone agrees that the targets set for energy efficiency and decarbonisation should be in line with internationally determined climate targets, hence this framework does not at all need to focus on environmental sustainability, 
and little consideration is needed regarding intergenerational equity, and such. Instead, the focus is on how the Renovation Wave might affect people during and after it has taken place.

Ideally, when creating a justice framework for whatever it may be, we want to find more directly applicable derivative normative considerations that all reasonable fundamental normative theories can agree upon. Normative theories relevant for the distribution of benefits and burdens will be presented in Section 4.1; from these, a framework consisting of normative principles relevant for the particular subject area will be derived in Section 4.2; and the framework will finally be elaborated with more concrete policy recommendations for the Swedish context in Section 6. In bioethics, for example, there is a famous example of such a convergence often called "the four principles of bioethics" by Beauchamp and Childress [95], according to which people in health care, for instance, should do no harm and produce benefits while respecting people's autonomy and the principles of justice. These four principles have then been used in everything from practical guidelines on the shop floor, pertaining how to treat patients who do not want to subscribe to a medical regime that would benefit them in terms of giving them a better health, to how to set our priorities in a global pandemic. The upside with such a framework, which is in part why Beauchamp and Childress' principles have become so popular, is that it is transparent to everyone where the ultimate justifications lie, which implies that it is easy for others to understand, to challenge, and to build upon when new needs arise in the future.

\subsection{Procedures, Outcomes, and Currencies}

In the social justice debate, there are two main focal points: procedures (procedural justice) and outcomes (substantive justice) [96]. Knowing from Section 2 that economic as well as housing-related inequalities have implications for procedures as well as outcomes of renovations, we are inclined to consider both of these when deriving our normative framework. Remember that the goal here is to find a position that every (reasonable) normative theory can agree upon; this is why we need to apply the theories which, according to their proponents, would be relevant regarding our case.

\subsubsection{Procedural Accounts}

According to the pure proceduralist accounts, an outcome is just if, and only if (iff), it has been produced by a just or fair procedure. Thus, the outcomes do not make a difference in terms of justice when it comes to these views; only procedures have these effects. For example, if we have a just procedure (whatever that is), and this procedure produces extreme inequalities, these inequalities are to be considered just (e.g., [97]). So, if the free market is such a just procedure, then whatever effects this market has, these should be considered just.

There are a number of procedural accounts but according to the most developed accounts, such as Daniels and Sabin's Accountability for Reasonableness (A4R) [98], which has been applied to a large extent in the discussion about priority setting in health care, (1) people affected by a decision need to be informed by the decision (i.e., decisions and their rationales must be public); (2) the rationales need to appeal to evidence, reasons, and principles that are accepted as relevant by fair-minded people who are disposed to finding mutually justifiable terms of cooperation; (3) there must be mechanisms for challenge and dispute resolution regarding limit-setting decisions, and, more broadly, opportunities for revision and improvement of policies in the light of new evidence and arguments; and (4) there must be a voluntary or public regulation of the process to ensure that conditions 1-3 are met [98] (p. 45). The "fair-minded people" mentioned here can either be those who are affected or others such as people of the court or the people's representatives, just to mention a few examples. In addition, everyone needs to be well-informed, reasonable, and the worst-off must be represented on an equal footing in order to guarantee that this group can express themselves freely without being censored or censoring themselves (cf. [99]) (for a similar view, see also the vast discussion on "the ethics of risk" where Sven-Ove 
Hansson, among others, argue that those who are put at risk should also have influence over the decision being made (and preferably also reap the possible benefits) (e.g., [100]). This is in line with most procedural theories in a situation such as the Renovation Wave, where the worst-off are disenfranchised while at the same time being at the greatest risk of being negatively affected from the upcoming renovations.

Of course, these procedures could be situated at different levels, such as at the microlevel for the tenants in an individual building, the meso-level at the level of the municipality, or the macro-level, which could be the central government. This will not be further elaborated on here other than that if one really wants to make sure that the procedure is fair according to 1-4, there will most likely be a need for a voice from the people who are affected by the Renovation Wave; this so that both the arguments from their perspective arise, and so that the strength of these arguments are understood. Another point to make here is that there is (perhaps too much) leeway in how to understand what constitutes A4R. For example, how should we define a "fair-minded individual"? Now, some of these issues should be solved in actual debates. Compare with common law systems where you need to argue your point in cases, and where judges can use precedents from previous cases as support for what to think in the current case but who also listen to new arguments and can thereby produce a new precedent. There will also be a lot of cases where most people simply will have the same opinion. Lastly, normative theories, such as the outcome-based (or end-state) theories discussed in the next paragraph are usually thought to be a part of what it means for a person to e.g., be "fair minded".

\subsubsection{Outcome-Based Accounts}

According to pure outcome-based theories instead, an outcome is just, iff the outcome has certain patterns such that it is just. There are a number of theories specifying what these features are but the main difference between the pure procedural accounts and the pure outcome-based accounts is that for the latter how the outcome was produced makes no difference, only that the outcome has a certain set of features. For example, if great inequalities are by the outcome-based accounts considered to be unjust, then it does not matter from the point of view of justice if it was produced by, e.g., voluntary choice-it is still unjust. There are many outcome-based theories but the most common ones relevant to the case of the Renovation Wave in a context of inequality are those of sufficientarianism (e.g., [101,102]), egalitarianism (e.g., [103,104]), prioritarianism (e.g., [105,106]), utilitarianism (e.g., [107,108]), and desert (e.g., $[109,110])$ (there are other theories which also might be relevant here such as luck-egalitarianism [111] or theories about recognition [112]; however, we believe that the implications in terms of reasoning and outcomes of the theories being left out are encompassed by the combination of normative theories and values discussed in this paper).

Very roughly, according to these theories, an outcome is just, iff everyone is over a sufficiency threshold; everyone is equally well of; the value is maximised but where every incremental increase in value counts for more for the least well-off; maximising the value where everyone's increase in value counts equally; or giving people what they deserve. So, for example, if we are prioritarian, we believe that one unit of subjective well-being is worth more when it is given to someone who is worse off than another, which in turn gives us reason to distribute this unit of well-being, ceteris paribus, to the worse off individual. However, if we were utilitarian instead, ceteris paribus, we would not have any decisive reason to give the unit of well-being to the one in favour of the other since the total amount of well-being in the world would be same in both cases. Or, if we are "desertian", it can actually be a bad thing to give someone a benefit if undeserved, even under the assumption that it would go to waste otherwise. Thus, when evaluating a range of alternatives, we should according to these theories choose the alternative where (1) people are sufficiently well-off; (2) where everyone is equally well-off; (3) where those who are the worst off have been given priority; (4) where the value is maximised; and (5) whether people get what they deserve. 


\subsubsection{Currencies}

There are a range of potential values when discussing justice in relation to the Renovation Wave to be sure, but the ones we are going to focus on here are those who are the most elaborated and are sometimes called "currencies of egalitarian justice" (e.g., [113,114]). These chief contenders today are well-being, capabilities, and resources (of course, there are other currencies as well, such as "advantage" [114]; we will not discuss these here for the same reasons as noted in earlier). When it comes to well-being, there are broadly three theories: hedonism, desire theories, and objective list theories (e.g., [115,116]). What makes a life good is simply speaking to feel good, to have your desires fulfilled, or to have a life with characteristics that are objectively valuable. When it comes to objective list theories, the characteristics can range from having a meaningful job; living in a decent community; to having deep and meaningful relationships; to get recognition; or to have control over one's living environment-just to mention a few examples (see, e.g., [115]: 286-367, [117]). Of course, many of us desire and would take pleasure in all these things, but according to the objective list theory, these are building blocks of a good life, whether we want them or not. Now, according to some variations of these theories, our well-being is not measurable in principle and much less so in practice. We will set these aside and focus on the ones according to which we can measure states of well-being. What has been found in psychological research is that hedonism and desire theory can come apart, so we need to measure both to be sure that we measure what is of value. To measure well-being, we also need a validated measure. Three of the most widely used ones are the Positive and Negative Affect Schedule (PANAS) for hedonism [118], the Satisfaction with Life Scale (SWLS) for desire theory [119], and the Questioner for Eudemonic Well-being (QEWB) [120].

When focusing on capabilities and resources instead (the capability approach, the human development approach) we should aim for giving people capabilities that make them able to pursue a functioning of different sorts (i.e., realizing the capabilities) and through this a dignified and flourishing life [121,122]. There are different views on what these capabilities are, but Nussbaum [122] has presented and defended the most elaborated account on social justice where the basic capabilities are (1) Life; (2) Bodily health; (3) Bodily integrity; (4) Senses, imagination, and thought; (5) Emotions; (6) Practical reason; (7) Affiliations; (8) Other species; (9) Play; and (10) Control over one's environment. In Nussbaum's framework, these basic capabilities are open for interpretation but there are still many clear cases when these are violated, and there are ways in which this framework has been operationalized (see, e.g., [123]). Lastly, we have the resourcist view, which is very similar to the capability view, which states that we should aim to give people resources to be able to pursue a dignified and flourishing life with self-respect. These resources can be, e.g., "primary goods" [124], such as income, education, and health. Again, there is some unclarity here as to what should count as a basic good and how these should be measured; however, there are many clear instances when these are violated and there are also operationalizations of these views (see, e.g., [125]).

In our discussion thus far, natural- and absolute rights have been conspicuously absent, and this will continue to be the case. To the degree we can limit the moral considerations and thereby making the framework simpler, this is to be preferred. Thus, we will leave out the more controversial views, such as the idea about absolute natural rights (e.g., [97]), partly because we have found it to be incoherent, and partly because it would not have much practical use in the debate about the Renovation Wave (for references and discussion, see, e.g., [126]). Other non-absolutist rights, sometimes called prima facie rights (e.g., [127]), could be derived from-and are compatible with-the normative theories presented above.

\subsection{The Preliminary Framework for Just Energy Transitioning}

As we saw in Section 4.1, a range of fundamental normative principles are relevant when discussing the Renovation Wave. To simplify matters somewhat, a first step is to get a more operational framework regarding how to approach these matters. This 
framework and its plausible effects should after consideration be acceptable for most people. Accordingly, we will use the normative theories in Section 4.1 together with general facts about the situations different groups of people are in, in conjunction with what in most cases is practically feasible, and base our framework on that.

Beginning from the end, we propose the following framework named "Framework for Just Energy Transitioning" according to which we should:

(1) Not discriminate against people on morally irrelevant grounds, such as their ethnic, religious, sexual (etc.) orientation (the equal treatment principle).

(2) Prioritize the needs of the worst-off, with an increase in priority the worse off they are (the priority principle).

(3) Produce the maximum benefit (in terms of well-being, capabilities, and resources) per resource unit (the efficiency principle).

(4) Use a transparent procedure where decisions are made by reasonable, fair-minded, well-informed, and cooperative people, among which are those who are (potentially) negatively affected, under equal terms, and where the decisions being made can be appealed (the principle of procedural fairness).

○ Compare with Sovacool and Dworkin's [94] definition of energy justice: “We define an energy-just world as one that equitably shares both the benefits and burdens involved in the production and consumption of energy services, as well as one that is fair in how it treats people and communities in energy decision-making. In other words, we see importance to both substantive outcomes and decisional procedures".

The basic idea is that (1) serves as an overriding principle that cannot be violated, while (2) have priority over (3) even though this is not absolute, and (4) is used during the process of the Renovation Wave, but especially when priority setting is needed, and when we have to make (1), (2), and (3) more precise and perhaps also to add further principles. The "benefits" and "needs" that we refer to here are all three currencies mentioned in Section 4.1 (well-being, capabilities, and resources). Preferably, we should try to find solutions where all these currencies converge. However, if this is not possible, (4) should be used to adjudicate between the different values. Similarly, (4) should be used to make the currencies more precise to the extent this is needed (see, e.g., Nussbaum's [122] discussion about capabilities or Herlitz and Sadek [128] about public choice and indeterminacy).

There are some caveats and clarifications to be made when it comes to the aforementioned framework. First, the equal treatment principle together with some uncontroversial empirical statements follows from all the normative theories above and is a well-entrenched value in many societies today. According to all normative theories, ethnicity etc. as such does not matter morally and there are no empirical facts of the matter which gives us reason to believe that ethnicity should influence the distribution of final or instrumental goods. Of course, some people could be harder to benefit than others because of their world views (etc.); but, those are then reasons (from efficiency probably) for not giving the group priority, not that they belong to a certain ethnic group. Furthermore, since large-scale renovation projects might be used as a cover to get rid of groups of people because they are deemed to belong to the wrong group (think about the Roma population in Romania), it is necessary to state this principle explicitly in a framework concerning the Renovation Wave.

Second, motivated by the increasing economic inequalities and increasingly precarious housing situation among the worst-off, the framework states that we should prioritize the needs of the worst-off without giving these needs absolute priority. Of course, this follows nicely from prioritarianism since this is basically what the view entails, but it seems to us also to follow in most cases from the other theories as well. According to utilitarianism, the right thing to do is to maximize the total amount of benefits (over burdens). In many situations, this could be done by prioritizing the needs of the worst-off since this will lead to more resources to the worst-off, which according to the law of diminishing marginal of utility will result in a greater outcome of positive value than when giving the resources to the better off. More specifically, when renovating buildings, etc., those who are the worst 
off are in the greatest risk of being impacted most negatively, which, in turn, can be avoided given that we take care of not pursuing those routes where these risks are. Conversely, the same is not true when it comes to the segments of the population who are well-off. These will probably not be of any great risk of becoming worse off in terms of receiving a lower degree of well-being. For them, the changes in terms of higher rents, etc. will be far less noticeable and thereby cause them a much smaller drop in well-being. These considerations combined, i.e., the risk of loss in well-being for the worst-off while almost no such risk exists for the well-off, the right policy to take is to guard those who are the worst off while in exceptional circumstances deviate from this rule.

When it comes to sufficientarianism and desert instead, both theories stress that people should be sufficiently well-off, because, e.g., they deserve it by being agents (etc.). Accordingly, proponents of these views could argue that we thereby should give the worstoff absolute priority and not just priority as it is now. Even though this idea has merit, we believe that it is wrongheaded. First, if we give the worst-off absolute priority, we would get a normative principle that would forgo a vast amount of benefits, for a large amount of people, in order to help an extremely small number in an almost impeccable way. This is hardly something people would accept, which we have seen in other areas such as health care (see, e.g., [129]). People readily accept (in many cases) to prioritize the worst-off, but not to give them absolute priority; thus implementing such a view seems not practically feasible, and since "ought" implies "can", we do not have a moral obligation to prioritize the worst-off here in an absolute way since this cannot be done. Second, it is not clear that giving the worst-off absolute priority in the context of the Renovation Wave would make more people sufficiently well-off in general. We need to make some radical changes to meet the challenge of climate change, and if we do not, the worst-off will suffer most. Third, since most sufficentarians and "desertists" are pluralists, we actually do not expect that many from that camp will oppose our principle on sufficentarian or desert-based grounds; they will simply think that this is a measured response to the complex issue at hand.

Third, moving on to the efficiency principle, this follows nicely from utilitarianism and prioritarianism, given the empirical facts discussed above, and when the priority principle is given priority over the efficiency principle. Furthermore, all reasonable normative theories allow for efficiency considerations; not doing so would be vastly counterintuitive and hence a reductio against that theory. It is simply not plausible that efficiency should count for nothing when evaluating and constructing social policy, which implies that such (fundamental) normative accounts, on the face of it at least, can be discounted. The efficiency principle also nicely explains what many people find to be wrong with giving absolute priority to those with the greatest needs. In certain contexts, absolute priority will simply yield too large losses in final values (such as energy savings), which is perceived as inefficient in the sense that they could make much more good elsewhere. Exactly where the cut-off point should be drawn is a moot question, of course, but, according to us, it should be set using a fair process by the agents involved and will thus not be done here. The principle of procedural fairness could in turn be grounded in the above mentioned fundamental normative theories together with the empirical facts of the situation. However, we will not do that here since we believe that the wider trend in political philosophy of using procedural accounts as a complement to the non-procedural ones when these does not, e.g., give a determinate answer or are in competition with each other in different ways (see, e.g., Nussbaum [122], Brandstedt and Brülde [130], and Herlitz and Sadek [128]) is justified. Using these procedurals accounts in this way should also not be objected to by the proponents of the procedural accounts since this does not impede on the use of any of the reasonable versions of these accounts.

Fourth, and last, when we are saying that people should be "cooperative", this is only meant when we have a situation where everyone is cooperative and fair minded. So, for example, according to our framework there is no need to for tenants who are among the least well-off to be cooperative in relation to landlords who want to evict them only to make greater profits. This is because the landlords in this scenario are not fair minded 
or cooperative. However, it might be the case that a landlord actually has to increase the rents somewhat in order to get an economically sustainable solution. In these kinds of scenarios, the tenants have a responsibility not just to flatly deny any increase in rent but need instead examine if something else could be done to keep the rents as before or accept, if reasonable, a rent increase. Similarly, just because those who are potentially negatively affected should have a voice in the proceeding, this does not imply that they should be able to decide what we should do in a given situation. Their position and arguments should count as everyone else's and in a representative democracy; for instance, it is not clear that people from the affected groups should have representatives other than those they selected to represent themselves in parliament. Of course, these are thorny issues and they will need to be resolved through debate in the settings in which they arise in a fair-minded and cooperative manner.

To conclude this section, Figure 4 shows how fundamental normative theories and final values have been considered within the context of imposing the Renovation Wave on an increasingly unequal housing market, to finally form the normative framework for just energy transitioning.

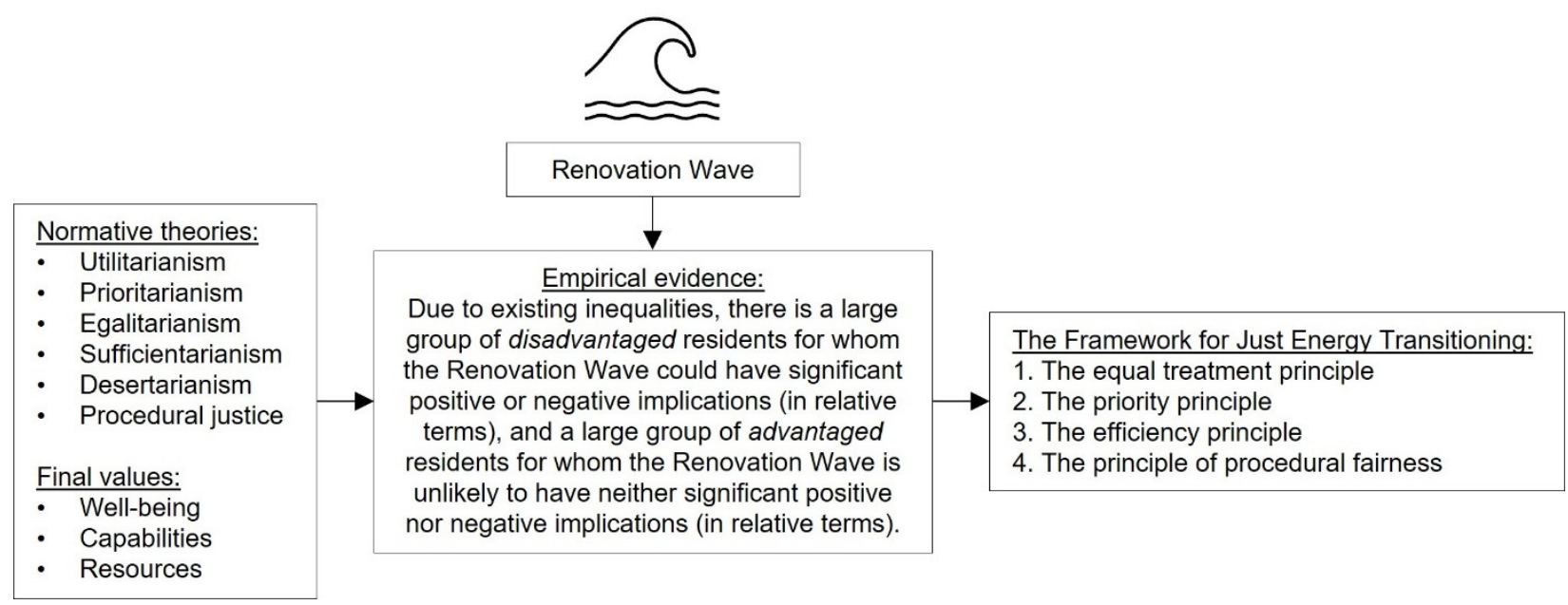

Figure 4. Normative and empirical grounds for the development of the normative framework.

\section{Analysis of How the Reduction of Energy Use Affects People}

To achieve deep energy retrofits within the Renovation Wave, and to reach the ambitious energy efficiency targets in the Swedish housing stock, both the technical and behavioural approaches are likely to be used in all parts of the housing stock but with a focus on where these measures are most effective. However, the most effective measures in terms of "bang for the buck" or political expediency might affect the worst-off in an unjust way. We thus need to analyse the different measures carefully in order to align ecological and social sustainability targets.

In this section, we are going to discuss the three broad approaches, the technical solutions, the behavioural solutions, and the area-efficiency approach. This will be done by combining the normative framework from Section 4 with the empirical work from Sections 2 and 3, to analyse what might need to be in place in order to avoid negative social effects while preserving the positive ecological ones. All of this will be firmly situated in the Swedish context.

\subsection{Energy Retrofitting}

As shown in Section 3, technical solutions can be very effective when trying to reduce the energy use in the housing stock and they constitute the heart of the Renovation Wave. There are many ways to implement these solutions on a societal level, but perhaps the most common solution when it comes to solving almost any problem is to use our resources in 
the most cost-efficient manner. Here, this would mean that we should try to improve the energy performance in buildings where the greatest energy savings could be achieved at the minimum cost and climate impact; this is reflected in Swedish policy as well as in the Renovation Wave by prioritising the buildings with the lowest energy performance, where there are often low-hanging fruit in terms of energy savings.

There are several problems with this cost-maximization approach according to our preliminary framework for just energy transitioning, which suggests that maximum benefit and minimum harm should be achieved while particularly considering the implications for the worst-off. Now, the careful reader will find that we are not (explicitly) using the instruments for measuring the final values in Section 4.2; this does not imply that they are not used implicitly, of course, but the main reason for not discussing the finding with these instruments is simply because they are not needed to make the more general points we want to make here. However, these instruments will be crucial when we want to deepen our understanding and reasoning concerning how to create a just Renovation Wave.

First, the worst-off are overrepresented in buildings with low energy performance and will thus be living in the most salient targets for renovation. Given the current situation on the Swedish housing market, where pressure to increase rents in low-income areas is high and profitability in substantial energy efficiency measures is low, low-income tenants are exposed to a risk of increased rents when extensive energy retrofitting projects are stimulated and/or imposed. Regardless of its magnitude, an increased rent will always burden the worst-off more than the rest of the population as the rent already makes up a greater part of monthly expenditures in low-income households. This means that an increased rent in the part of the housing stock where the worst-off are overrepresented is more likely to imply trade-offs with other expenditures, economic distress, and primary or secondary displacement than it is in any other part of the housing stock. According to our preliminary framework for just energy transitioning, this gives us strong reasons to limit stimulation of retrofits among the worst-off. Targeting these buildings through e.g., minimum requirements for energy performance would require either regulations that limit the rent increases or subsidies to cover rent increases over a certain level in order to protect the most vulnerable residents.

Second, the least well-off are sometimes below the sufficiency threshold and are worseoff in relative and absolute terms than other groups in society. When a group is below the sufficiently threshold, we have strong justice-based reasons to raise them above and not push them further below the threshold. Of course, one way to improve the situation for those worse-off, considering they are overrepresented in energy-inefficient buildings, could be to improve the energy efficiency of their housing. Energy retrofitting will most likely improve the indoor environment, but as described above, this will also entail a risk for increased rents. It thus becomes a question of whether the risk for increased rent can be compensated by improvements in final values brought on by an improved indoor environment, such as increased comfort and health.

Acknowledging the plethora of aspects that contribute to how these benefits and burdens balance against each other, e.g., the health conditions of residents and the building's indoor climate, it can be argued that, in general, the benefits do not outweigh the burdens in a Swedish context. This is because of the generally high standard of building insulation and indoor environment in Swedish housing, meaning that the indoor environment rarely is poor enough to constitute a significant health risk or a main stressor and/or insufficiency among the worst-off. In countries with widespread issues of energy poverty, the reality of the respective benefits and burdens is of course different as the energy-related costs and health-effects weigh heavier.

In addition, systematic rent increases in low-income housing occur in the context of increasing economic inequality, lack of affordable housing, and a precarious housing market. Protecting the worst-off thus also means to protect the remaining (yet insufficient) supply of affordable housing, as demand is increasing more rapidly than supply. This motivates trying to limit quality upgrading renovations in the affordable housing stock, 
which, in turn, motivates avoiding extensive and unprofitable energy retrofitting in general. For individual households, the economic burden of paying rent can be assumed to be a greater burden among the worst-off than the burden of a sub-optimal yet adequate indoor environment. Consequently, a decreased economic standard owing to increased rent is likely to, in a Swedish context, push the worst-off further below the sufficiency threshold, with little or no compensation in terms of comfort and health. Returning to our preliminary framework for just energy transitioning, we thus find that we generally should limit the imposition of energy retrofits among the worst-off to protect them from rent increases, but that energy retrofits in individual cases can be motivated by a significant increase in thermal comfort and indoor climate, thus leading to increased comfort and health.

Third, the problems from the principal of procedural justice in our framework is that the tenants being put at the frontline of the maximization energy reduction strategy do not have the control needed over their homes in order for the criteria of procedural justice in our preliminary principle to be fulfilled. There are two main reasons for this: (i) the precarious housing situation among the worst-off, directly disarming residents of their power; and (ii) the power of landlords and their strong advantages in legal procedures. The increase in economic inequality, residential segregation, and overcrowded apartments has resulted in a deeply polarised housing market where some have primary and secondary residences while others have third- or fourth-hand leases. The latter groups almost have no power in terms of control in relation to their living situation, and their rights are close to non-existent. Furthermore, the precarity of the situation, at times considered illegal, means that residents sometimes are safer and better off if silent and/or conformable in retrofitting procedures. In these extreme cases, procedural justice is difficult to ensure, which implies that decisions taken here do not accord to procedural justice and the outcomes would thereby be unfair. In cases where renters hold a first-hand lease, conditions for procedural justice are better, but statistics for court rulings suggest that tenants' position against landlords in retrofitting processes remain weak.

To achieve a just energy transition of the housing stock according to our preliminary framework, we are thus inclined to either minimise imposition of energy retrofits among the worst-off or to increase tenant influence in retrofitting processes. Although there would be many benefits from the latter, the urgency of energy efficiency targets still suggests that maximum benefit and minimum harm could be achieved by putting a less vulnerable part of the population at the frontline of the energy transition. As higher income earners tend to live in their own houses or in tenant-owned apartments, where they have both great insight and control over what is done with their homes, they have, at least in general, access to procedures where they can make decisions that could be perceived as fair according to our preliminary framework.

In conclusion, we find that considering the current situation on the housing market, characterised by energy-, economic-, and housing-related inequalities, where private housing companies in particular are prone to maximising profit with little or no consideration of tenants, our normative principle with a focus on the worst-off gives us strong reasons to not initiate the Renovation Wave in the worst-performing part of the multifamily building stock, as suggested by a general maximisation strategy without subsidies or other forms of protection. Although improved energy performance of housing is needed and would benefit the residents among the worst-off, it would be more justifiable to focus on less extensive retrofitting in these areas, where energy performance is improved but not to the extent that is promoted through deep retrofitting in the Renovation Wave. The more extensive the retrofitting project is, the greater the tension between energy savings and profitability will be, which, in turn, will increase the risk of landlords carrying out rentincreasing measures. Less extensive energy retrofitting will thus reduce the risks for the worst-off, but when carried out on a pressured housing market, there will still be incentives to include rent-increasing measures in the retrofitting project. Overall, motivated by an immediate concern for the worst-off residents as well as a long-term concern regarding the 
supply of affordable housing, our normative principle advises us to limit the imposition of extensive energy retrofits among the worst-off.

If we, for political or ecological reasons, must prioritise energy retrofitting in these buildings despite the associated risks, it is of high importance to establish regulations and/or procedures that minimise the risk of harming the worst-off. For example, we might enact policies that compensate for the demands put on the least well-off, such as housing allowances in cases where imposed energy retrofits lead to a plethora of retrofitting measures, ultimately increasing the rents. Another alternative is to give the tenants more power over their living situation, by e.g., demanding that tenants must be able to choose from different renovation options in their apartment interior with different levels of rent increases, where the least expensive option preferably cannot entail any rent increases at all.

\subsection{Economic Incentives for More Energy-Efficient Behaviour}

Although the realistic energy savings potential from behavioural solutions are not thought to be as great as from technical solutions, their impact remains valuable and they constitute an important part of the EU's energy-efficiency policy. Behavioural solutions are to some extent more compatible with our framework than the technical ones, since the behavioural solutions are more voluntary in nature; this is because, for instance, people receive more capabilities in these contexts, and the worst-off can opt out if they want to and therefore are not as negatively affected as when the solutions are involuntary. Nevertheless, economic incentives for more energy-efficient behaviour will in many cases be more "effective" in households where economic resources are limited, and may, as we shall see, entail various risks for low-income households. The efficacy of such measures also depends on energy prices and the residents' potential to adjust one's energy use. In single-family houses, all energy use is already metered and billed per individual household, meaning that implementation of policy becomes relevant in multifamily buildings only. Household electricity use is already metered and billed individually in most multifamily buildings in Sweden, while energy for heating and domestic hot water remain collectively managed in most multifamily buildings.

The premises for individualisation of energy for heating and energy for domestic hot water differ; while the potential to reduce energy use for heating through behavioural changes decreases as buildings' energy performance improve, the potential to reduce energy use for domestic hot water remains high regardless of buildings' energy performance. A cost-effectiveness maximisation strategy will thus put a focus on worst-performing buildings in the case of energy for heating, but not in the case of energy for domestic hot water. Starting with the latter, we know that although individualisation of metering and billing of energy for domestic hot water does not particularly put a focus on the worst-off, it has been shown that the worst-off are disproportionally burdened by such measures in terms of increased costs, as the number of residents per household tends to be higher among the worst-off in combination with more time spent at home owing to, e.g., unemployment and long-term illness.

Although individual metering and billing of energy for domestic hot water is by many considered a more fair option than the collective method-as it after all removes issues of households under- or over-paying for their water consumption-the effects of individualising hot water consumption will in many cases imply a severe increase in costs among the worst-off. Consequently, it is not excessive water consumption that will be primarily penalised, but rather a larger-than-average household size; this in spite of the fact that a larger household size significantly reduces households' overall resource use as well as per capita water consumption.

Returning to our preliminary framework for a just energy transition of the housing stock, we find that in order to protect the worst-off from significant increases in energy costs and the negative effects this brings to their well-being (etc.) given their precarious financial state, we have reasons to avoid implementation of individual metering and billing of energy for domestic hot water among the worst-off. It is likely that the burden of increased 
energy costs will be smaller in more affluent parts of the housing stock, and the likelihood to accurately target excessive water consumption rather than "excessive" household size will be higher.

Considering the case of energy for heating instead, we know that such policy disproportionately affects the worst-off as maximisation strategies target worst-performing buildings. This was evident in the regulation that was recently passed in Sweden, demanding individual metering and billing of energy for heating in worst-performing multifamily buildings. Hitherto, little is known regarding how the worst-off will be affected by this new regulation. Of course, the implications will be highly dependent on local energy prices for heating as well as the building's heating system, where e.g., heat pumps significantly contribute to a lower heating cost. We can, however, assume that there are very few heat pumps among the worst-performing buildings.

Nevertheless, among the worst-off, heating cost might be an expenditure that is worth compromising to afford other necessities, especially during the colder winter months. As heating costs, when part of the "warm rent", are equal each month throughout the year, the new cost, although perhaps not higher in total, will be distributed differently over the year. It is not evident that this constitutes a burden; however, as heating costs are the highest when outdoor temperature is the lowest, there is a risk that those who are economically worst-off will try to limit their heating demand during the colder months (when heating costs peak) and thus experience an impaired indoor environment and perhaps suffer from negative health implications. Although it can be argued that the higher heating costs during winter should be compensated by the lower heating costs during summer, it can be questioned to what extent such a redistribution of expenditures will actually be successful. Returning to our normative framework for just energy transitioning, we thus find that we have reasons to either exempt the worst-off from implementation of individual metering and billing of energy for heating, or to implement policies, e.g., subsidies or landlords measuring indoor temperature in apartments, to ensure that sufficient heating can be provided to sustain an adequate indoor climate and thermal comfort.

\subsection{Reducing per Capita Living Space}

We have seen that when targeting buildings' energy performance, maximisation strategies inevitably point towards the worst-performing buildings, where worst-off residents are overrepresented. However, when targeting per capita energy use, we find the least efficient individuals, i.e., those with the greatest energy use per capita, among the best-off owing to a relatively large living space per capita in this segment. In the Renovation Wave, as well as in most energy performance policies, there is a one-sided focus on buildings' energy use, with little or no recognition of people's energy use in terms of how much heated housing area different groups in society are claiming, as well as the use of other resources, such as water and materials, that an increased area use entails. This one-sided focus leads to a neglect of the economic inequalities that cause high-income earners to afford large, yet energy-efficient housing, and low-income earners to afford small, but energy-inefficient housing. To some extent, this strong consideration of technology rather than practices makes current energy performance policies unequal and arguably inherently targeted towards the worst-off.

The increasing differences in living space per capita in Sweden-where high-income earners have increasing or unchanged living space per person whereas low-income earners are living on smaller and smaller areas per person-have several implications for what constitutes just energy transitioning. Among the lowest income earners, there has been an increase in overcrowded apartments, meaning that there is an increasing number of households with insufficient access to living space per capita and a decrease in well-being and health. As argued above, our preliminary framework for just energy transitioning gives us strong reasons to not further impair the situation for the worst-off. However, considering the increasingly frequent over-crowdedness, we also have strong reasons to improve the situation by increasing the living space per capita among the worst-off. Among 
the highest income earners, there is instead an excessive use of living space, and thus energy, per capita, suggesting that living space could be reduced; of course, without pushing households below a sufficiency threshold and into over-crowdedness. In other words, there is a growing need for a redistribution of area in the housing stock.

Although this remains unrecognised in energy policy, our normative framework for just energy transitioning suggests that a reduced living space per capita among the highest income earners could be a just means to reduce energy use in the housing stock. This could simultaneously reduce excessive energy use among the best-off and make living space available for over-crowded households. Of course, policy of this kind is likely to face a lot of resistance, and it is also unlikely that the released living space among the best-off would be economically available to the worst-off. Nevertheless, there are means in which such a redistribution of living space could be indirectly performed.

One example is through re-implementing progressive property taxation. It is likely that such taxation to some extent would limit the living space per capita in the wealthiest part of the housing stock, while at the same time redistributing wealth to the worst-off. This would reduce economic inequalities, and the improved economic standard among the worst-off could in turn allow them to access greater living space per capita. The multiple benefits of such taxation could thus be that energy use is reduced, that economic and living standard is improved among the worst-off, and that the root of the challenge for a just energy transition-economic inequality-is counteracted as well. In light of our normative framework for just energy transitioning, we have strong reasons to question the fact that energy retrofitting is requested in overcrowded low-income multifamily housing while little political action is being taken to reduce the excessive use of space, and thus energy, in the villas and summer residences in higher-income segments.

\subsection{Summary of Analysis}

What we find from the above analyses is that both technical and behavioural solutions entail higher risks for the worst-off than for the rest of the population, whereas area-related solutions are likely to burden the most well-off more than the worst-off. This is shown in Table 2. What we know from Section 3 is that among these three main approaches, the former two dominate in terms of recognition and reliance for energy savings. Yet, these approaches evidently risk leading to immediate injustices for individual residents and could also contribute to increased long-term inequalities by limiting the supply of affordable housing, which, in turn, will have a negative impact on the well-being (etc.) of the worse-off and hence be unjust according to our framework. More so, we find that Sweden is currently implementing policies to economically incentivise residents to reduce their energy use, an approach that has relatively low energy-saving potential according to empirical evidence and that has relatively low compliance with our framework (Table 2). It thus seems as if this approach in a Swedish context has a relatively high risk and relatively low reward, which should be considered moving forward.

Table 2. Summary of Section 3 combined with the results from the analysis in Section 5.

\begin{tabular}{cccc}
\hline Approach & Energy Savings Potential & $\begin{array}{c}\text { Part of Housing Stock with } \\
\text { Largest Potential } \\
\text { (Maximisation Strategy) }\end{array}$ & $\begin{array}{c}\text { Recognition } \\
\text { (Housing Stock Level) }\end{array}$ \\
\hline $\begin{array}{c}\text { Improved technical } \\
\text { performance } \\
\text { (Renovation Wave) }\end{array}$ & High potential & $\begin{array}{c}\text { Greater potential and higher } \\
\text { cost-effectiveness in buildings } \\
\text { with low energy performance }\end{array}$ & $\begin{array}{c}\text { Highly recognised } \\
\text { and endorsed }\end{array}$ \\
\hline $\begin{array}{c}\text { Economic incentives } \\
\text { for more } \\
\text { energy-efficient } \\
\text { behaviour }\end{array}$ & Relatively low potential & $\begin{array}{c}\text { Slightly greater potential in } \\
\text { buildings with low } \\
\text { energy performance }\end{array}$ & $\begin{array}{c}\text { Recognised but not } \\
\text { highly endorsed }\end{array}$ \\
\hline $\begin{array}{c}\text { More efficient use of } \\
\text { living space }\end{array}$ & Can reduce demand for \\
new construction & $\begin{array}{c}\text { Primarily affluent parts of } \\
\text { housing stock where living space } \\
\text { per capita is large }\end{array}$ & Unrecognised \\
\hline
\end{tabular}


The results in Table 2 can be understood as a mismatch between the most feasible approaches in terms of energy savings and the most acceptable approaches according to our framework for just energy transitioning. Looking at the energy transition of Swedish housing from an overall perspective, the mismatch in Table 2 reflects a lack of recognition of how economic inequalities allow high-income earners to afford large, yet energy-efficient housing, and low-income earners to afford small, but energy-inefficient housing, and how this in turn influences energy use among different income groups.

The conflict between the most recognised and relied-upon approaches in terms of energy savings and the most acceptable approaches in terms of social justice calls for new approaches and/or policy and subsidies that effectively bridge this mismatch. In some cases, policy and subsidies could target both sustainability pillars with one policy, such as green rent subsidies, or the establishment of pooled resources for long-term investments. Unfortunately, decision makers do not only need to take the societal targets into account; political constraints and time constraints also often dictate what is possible to achieve. To navigate these issues of different societal targets and constraints, a clear decision tree can assist decision makers when making decisions on these complex matters. The following example showcases how this could be done:

During the spring of 2021, the authors of this article worked for the Swedish authorities and provided analyses of the building stock for the development of an energy-efficiency subsidy scheme. A simple decision tree was provided that can be summarized into the following steps: (1) change the legal framework for the housing industry to allow long-term investments through pooled or accrued funds; (2) if the budgeted subsides need to be spent during this term, then implement green rent subsidies that address both social and environmental targets; and (3) if it is not possible to merge targets for political reasons, then add funding also for conventional support programs for disadvantaged groups affected by the renovation subsides, such as housing subsidies or welfare levels.

Based on the analysis in this section, the following section will revisit the preliminary framework for just energy transitioning and further detail how the different approaches can be carried out in accordance with this framework by extending it with concrete policy recommendations.

\section{Policy Recommendations for the Swedish Context}

Starting with a selection of normative theories relevant to the case of the Renovation Wave in a context of economic and housing-related inequalities, a Framework for Just Energy Transitioning was derived in Section 3, stating that the energy transition of the housing stock should comply with the following ordered principles:

(1) The equal treatment principle;

(2) The priority principle;

(3) The efficiency principle;

(4) The principle of procedural fairness.

Based on the analysis and discussion in Section 5, we are now in a better position to offer more concrete policy recommendations for the Swedish context grounded in the Framework for Just Energy Transitioning; this is shown in Figure 5, which also in a transparent way shows the schematic process through which the framework was developed and the final policy recommendations derived. The policy recommendations echo the conclusions that were drawn in Section 5, but also provide some preliminary suggestions of how the identified mismatch between effective approaches for energy savings and socially just approaches for energy savings can be bridged. These policy recommendations should be seen as an initial step in the discussion on how to achieve a socially just energy transition of the Swedish multifamily building stock in general, and a socially just Renovation Wave in particular. 
Normative theories:

- Utilitarianism

- Prioritarianism

- Egalitarianism

- Sufficientarianism

- Desertarianism

- Procedural justice

Final values:

Well-being

- Capabilities

- Resources

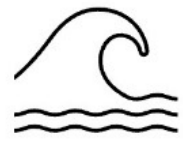

Renovation Wave

ncreased rate and

depth of renovations,

potentially forcing

non-profitable energy retrofits

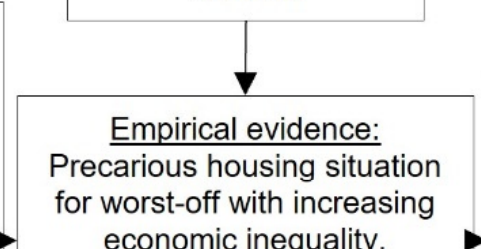

economic inequality

housing inequalities, and a

general pressure among

landlords to increase rents

\section{The Framework for Just Energy} Transitioning:

1. The equal treatment principle

2. The priority principle

3. The efficiency principle

4. The principle of procedural

fairness

Policy recommendations:

- Limit imposition of extensive energy retrofits among worst-off (Renovation Wave)

1. Prioritise renovations in areas where tenants either can afford potential rent increases, or where tenant influence is high. 2. If this cannot be achieved, maximise tenant influence among worst-off in renovation

processes; e.g. regulation requiring landlords to offer tenants different renovation options where the least extensive renovation entails no rent increase.

match identified

between most

recognised and feasible approaches for energy savings and most just approaches according to the framework
- Exclude worst-off from requirements of individual metering and billing of energy 1. If not possible, ensure that economic incentives for behavioural change targets excessive consumption rather than e.g. large household size, and that risks for energy poverty are managed

- Recognise importance of decreased living space per capita for reduced energy use 1. Benefit efficient use of living space and/or burden excessive use of living space; or facilitate redistribution of area in the housing stock by e.g. changing property taxation and/or housing allowances.

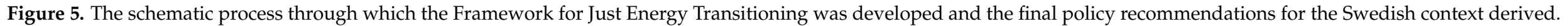




\section{Conclusions Regarding a Just Renovation Wave in the Swedish Context}

The energy transition as a whole is occurring under an era of increasing economic inequalities, and the Renovation Wave will roll over an unequal housing stock where consideration must be given to the unequal abilities among residents to influence and afford energy retrofitting. This means that measures for reduced energy use in the housing stock must be targeted to where the risks for negative social consequences are the smallest, while also being effective in their quest to reduce energy use. By considering the Swedish case-where social benefits of the Renovation Wave are expected to be relatively low due to the general lack of energy poverty and relatively high housing standards-a normative framework for a just energy transition of the housing stock was developed. The framework utilised normative theories relevant to the distribution of benefits and burdens between different social groups, from which principles that were of particular relevance to the Renovation Wave and the context of increasing economic inequalities on a pressured housing market were derived. For example, a priority principle giving special priority to the worst-off was considered important in the framework given the increasing economic and housing-related inequalities, and a principle of procedural fairness was considered important owing to the nature of renovation processes. The framework consists of the following four ordered principles that should be followed in order to achieve a just Renovation Wave:

(1) The equal treatment principle;

(2) The priority principle;

(3) The efficiency principle;

(4) The principle of procedural fairness.

By applying the framework to the Swedish context, we were able to evaluate the social justice implications of current and upcoming political strategies, such as the Renovation Wave, but also to identify less recognised approaches for reduced energy use in the housing stock that were more likely to be just according to our framework. It was found that in contradistinction to what is suggested in the Renovation Wave, we should avoid imposing the Renovation Wave among the worst-off and instead focus extensive energy retrofits, when motivated, in more affluent parts of the housing stock where vulnerability to rent increases is lower and tenant influence is likely to be higher. Among the worst-off, we find strong justice-based reasons for less extensive renovations that aim to maintain an adequate housing standard and protect the supply of affordable housing, and we also find reasons to limit implementation of economic incentives for more energy-efficient behaviour that risk creating new issues of energy poverty. Finally, it was found that efforts to reduce energy use through reduced living space per capita, a generally less recognised approach than energy retrofitting, could be an approach that unlike the Renovation Wave would not put the worst-off at the greatest risks in the energy transition of the housing stock, as it would target excessive use of living space in higher income segments instead.

The situation and challenges connected to housing and energy use are different in different EU member states, which means that the trade-offs between potential positive social outcomes and potential negative social outcomes from the Renovation Wave will balance differently. The Swedish case is an exception within the EU in terms of a high housing standard, a lack of energy poverty, and a lack of a social housing sector; but the context of increasing economic and housing-related inequalities is not unique to Sweden. Analysing trade-offs in the Renovation Wave will thus be equally important in other countries, and the normative framework developed for the Swedish context in this paper can thus be used as a model for similar nation-specific frameworks and policy recommendations in other jurisdictions. 
Author Contributions: Conceptualization, J.v.P., K.d.F.L., M.M. and K.M.; formal analysis, J.v.P., K.d.F.L. and M.M.; funding acquisition, M.M. and K.M.; investigation, J.v.P., K.d.F.L. and M.M.; methodology, J.v.P. and K.d.F.L.; project administration, M.M. and K.M.; supervision, M.M. and K.M.; validation, J.v.P., K.d.F.L., M.M. and K.M.; visualization, J.v.P.; writing一original draft, J.v.P., K.d.F.L. and M.M.; writing-review and editing, J.v.P., K.d.F.L., M.M. and K.M. All authors have read and agreed to the published version of the manuscript.

Funding: This work was funded by The Swedish Research Council for Environment, Agricultural Sciences and Spatial Planning (Formas), grant number 2017-01449, within the project National Building-Specific Information (NBI).

Acknowledgments: The authors would like to thank artist KonKa, Konstantina Katsela, for providing a graphical abstract for this paper; in doing so, she helped us communicate this research in a different, and perhaps more accessible, way.

Conflicts of Interest: The authors declare no conflict of interest. The funders had no role in the design of the study; in the collection, analyses, or interpretation of data; in the writing of the manuscript, or in the decision to publish the results.

\section{References}

1. EU. Buildings. 2019. Available online: https:/ / ec.europa.eu/energy/en/topics/energy-efficiency/buildings (accessed on 20 August 2019).

2. European Commission. The European Green Deal; European Commission: Brussels, Belgium, 2019.

3. A Renovation Wave for Europe-Greening Our Buildings, Creating Jobs, Improving Lives. 2020. Available online: https: / / eur-lex.europa.eu/legal-content/EN/TXT/?qid=1603122220757\&uri=CELEX:52020DC0662 (accessed on 16 June 2021).

4. Galvin, R. Inequality and Energy: How Extremes of Wealth and Poverty in High Income Countries Affect CO2 Emissions and Access to Energy; Academic Press: Cambridge, MA, USA, 2019.

5. Sovacool, B.K. Contestation, contingency, and justice in the Nordic low-carbon energy transition. Energy Policy 2017, 102, 569-582. [CrossRef]

6. Egholt Søgaard, J.; Roine, J.; Robling, P.-O.; Pareliussen, J.; Orsetta, C.; Lindgren, P.; Langørgen, A.; Hermansen, M.; Gunnarsson, K.; Calmfors, L.; et al. Nordic Economic Policy Review 2018: Increasing Income Inequality in the Nordics; TemaNord; Nordisk Ministerråd: Copenhagen, Denmark, 2018; p. 212.

7. Simcock, N.; Thomson, H.; Petrova, S.; Bouzarovski, S. Energy Poverty and Vulnerability: A Global Perspective; Routledge: London, UK, 2017.

8. Grossmann, K. Using conflicts to uncover injustices in energy transitions: The case of social impacts of energy efficiency policies in the housing sector in Germany. Glob. Transit. 2019, 1, 148-156. [CrossRef]

9. Grossmann, K.; Huning, S. Energy-Efficient retrofitting and affordable housing: Open questions for urban research and practice. In Proceedings of the RC21 International Conference on The Ideal City: Between myth and reality. Representations, Policies, Contradictions and Challenges for Tomorrow's Urban Life, Urbino, Italy, 27-29 August 2015.

10. Galvin, R.; Sunikka-Blank, M. Ten questions concerning sustainable domestic thermal retrofit policy research. Build. Environ. 2017, 118, 377-388. [CrossRef]

11. von Platten, J.; Mangold, M.; Mjörnell, K. A matter of metrics? How analysing per capita energy use changes the face of energy efficient housing in Sweden and reveals injustices in the energy transition. Energy Res. Soc. Sci. 2020, 70, 101807. [CrossRef]

12. Mangold, M.; Österbring, M.; Wallbaum, H.; Thuvander, L.; Femenias, P. Socio-Economic impact of renovation and energy retrofitting of the Gothenburg building stock. Energy Build. 2016, 123, 41-49. [CrossRef]

13. EU. Directive (EU) 2018/844 of the European Parliament of the Council of 30 May 2018 Amending Directive 2010/31/EU on the Energy Performance of Buildings and Directive 2012/27/EU on Energy Efficiency; EU: Brussels, Belgium, 2018.

14. EU. Directive (EU) 2018/2002 of the European Parliament and of the Council of 11 December 2018 Amending Directive 2012/27/EU on Energy Efficiency; EU: Brussels, Belgium, 2018.

15. EU. Communication from the Commission to the European Parliament, the Council, the European Economic and Social Committee of the Regions: Stepping up Europe's 2030 Climate Ambition Investing in a Climate-Neutral Future for the Benefit of Our People; EU: Brussels, Belgium, 2020.

16. Myers, M. Will the Renovation Wave Benefit the Energy Poor? 2020. Available online: https://www.euractiv.com/section/ energy/opinion/will-the-renovation-wave-benefit-the-energy-poor/ (accessed on 30 April 2021).

17. EU. Questions and Answers on the Renovation Wave. 2020. Available online: https:/ / ec.europa.eu/commission/presscorner/ detail/en/qanda_20_1836 (accessed on 30 April 2021).

18. Vad Innebär EU:s Renoveringsvåg för Allmännyttan? 2020. Available online: https://www.sverigesallmannytta.se/eusrenoveringsvag-lanserad/ (accessed on 30 April 2021).

19. Regeringskansliet. Överenskommelse om Sveriges Mål för Energieffektivisering. 2016. Available online: https://www.regeringen. se/pressmeddelanden/2016/11/overenskommelse-om-sveriges-mal-for-energieffektivisering/ (accessed on 30 April 2021). 
20. Sweden, S. Summary of energy statistics for dwellings and non-residential premises for 2000, 2001 and 2002. Stat. Swed. 2003, 304,36 .

21. Werner, S. District heating and cooling in Sweden. Energy 2017, 126, 419-429. [CrossRef]

22. Energiläget 2020; ET 2020:1; Swedish Energy Agency. 2020. Available online: https:/ / energimyndigheten.a-w2m.se/Home.mvc? ResourceId=168344 (accessed on 30 April 2021).

23. Boverket, Underlag till Den Tredje Nationella Strategin för Energieffektiviserande Renovering; Boverket: 2019. Available online: https:/ / www.boverket.se/sv/om-boverket/publicerat-av-boverket/publikationer/2019/underlag-till-den-tredje-nationellastrategin-for-energieffektiviserande-renovering/ (accessed on 30 April 2021).

24. Högberg, L. Incentives for Energy Efficiency Measures in Post-War Multi-Family Dwellings, in Trita-FOB-LIC; KTH Royal Institute of Technology: Stockholm, Sweden, 2011; p. 99.

25. Bouzarovski, S.; Simcock, N. Spatializing energy justice. Energy Policy 2017, 107, 640-648. [CrossRef]

26. Thomson, H.; Bouzarovski, S.; Snell, C. Rethinking the measurement of energy poverty in Europe: A critical analysis of indicators and data. Indoor Built Environ. 2017, 26, 879-901. [CrossRef]

27. Dubois, U.; Meier, H. Energy affordability and energy inequality in Europe: Implications for policymaking. Energy Res. Soc. Sci. 2016, 18, 21-35. [CrossRef]

28. Middlemiss, L. A critical analysis of the new politics of fuel poverty in England. Crit. Soc. Policy 2016, 37, 425-443. [CrossRef]

29. Member State Report Sweden. 2020. Available online: https://www.energypoverty.eu/sites/default/files/downloads/ observatory-documents/20-06/extended_member_state_report_-_sweden.pdf (accessed on 30 April 2021).

30. Johansson, B.; Jonsson, D.K.; Veibäck, E.; Mittermaier, E. Energifattigdom, Försörjningstrygghet och Offentligt Agerande. 2015. Available online: https://www.researchgate.net/publication/308048341_Energifattigdom_forsorjningstrygghet_och_offentligt_ agerande (accessed on 16 June 2021).

31. Ormandy, D.; Ezratty, V. Health and thermal comfort: From WHO guidance to housing strategies. Energy Policy 2011, 49, 116-121. [CrossRef]

32. Braubach, M.; Ferrand, A. Energy efficiency, housing, equity and health. Int. J. Public Health 2013, 58, 331-332. [CrossRef] [PubMed]

33. Kunkel, S.; Kontonasiou, E.; Arcipowska, A.; Mariottini, F.; Atanasiu, B. Indoor air quality, thermal comfort and daylight. Analysis of residential buildings regulations in eight EU member states. Build. Perform. Inst. Eur. 2015, 100, 1-6.

34. Thomson, H.; Snell, C.; Bouzarovski, S. Health, well-being and energy poverty in Europe: A comparative study of 32 European countries. Int. J. Environ. Res. Public Health 2017, 14, 584. [CrossRef] [PubMed]

35. OECD. An Overview of Growing Income Inequalities in OECD Countries: Main Findings; OECD. 2011. Available online: https: / /www.oecd.org/social/soc/49499779.pdf (accessed on 30 April 2021).

36. OECD. Sweden Policy Brief: Inequality; OECD. 2015. Available online: https://www.oecd.org/sweden/sweden-achievinggreater-equality-of-opportunities-and-outcomes.pdf (accessed on 16 June 2021).

37. Scarpa, S. Looking beyond the neighbourhood: Income inequality and residential segregation in Swedish metropolitan areas, 1991-2010. Urban. Geogr. 2016, 37, 963-984. [CrossRef]

38. Mangold, M.; Österbring, M.; Overland, C.; Johansson, T.; Wallbaum, H. Building ownership, renovation investments, and energy performance-A study of multi-family dwellings in Gothenburg. Sustainability 2018, 10, 1684. [CrossRef]

39. Eurostat. House or Flat-Owning or Renting. 2019. Available online: https://ec.europa.eu/eurostat/cache/digpub/housing/ bloc-1a.html?lang=en (accessed on 16 June 2021).

40. Olsson, S. Bostaden som Politiskt Objekt och Vara: Kortfattad Bostadspolitisk Översikt Från Artonhundratalet till Tvåtusentalet; Melica Media: Göteborg, Sweden, 2010.

41. Holmqvist, E.; Turner, L.M. Swedish welfare state and housing markets: Under economic and political pressure. Neth. J. Hous. Environ. Res. 2013, 29, 237-254. [CrossRef]

42. Hall, T.; Vidén, S. The Million Homes Programme: A review of the great Swedish planning project. Plan. Perspect. 2005, 20, 301-328. [CrossRef]

43. Grander, M. New public housing: A selective model disguised as universal? Implications of the market adaptation of Swedish public housing. Int. J. Hous. Policy 2017, 17, 335-352. [CrossRef]

44. Regering, S. Utveckling och rättvisa-En politik för storstaden på 2000-talet. Proposition 1997, $98,165$.

45. Law (2000:1383) about the Municipalities' Responsibility for Housing (Lag om Kommunernas Bostadsförsörjningsansvar). 2000. Available online: https:/ / www.riksdagen.se/sv/dokument-lagar/dokument/svensk-forfattningssamling/lag-20001383-omkommunernas_sfs-2000-1383 (accessed on 30 April 2021).

46. Law (2010:879) about Municipal Real Estate Companies (Lag om Allmännyttiga Kommunala Bostadsbolag). 2010. Available online: https:/ / www.riksdagen.se/sv/dokument-lagar/dokument/svensk-forfattningssamling/lag-2010879-om-allmannyttigakommunala_sfs-2010-879 (accessed on 30 April 2021).

47. Grander, M. For the Benefit of Everyone? Explaining the Significance of Swedish Public Housing for Urban Housing Inequality. Doctoral Dissertation, Malmö University, 2018. Available online: https:/ / muep.mau.se/handle/2043/25068 (accessed on 30 April 2021).

48. Christophers, B. A monstrous hybrid: The political economy of housing in early twenty-first century Sweden. New Politi-Econ. 2013, 18, 885-911. [CrossRef] 
49. Müller, T.S.; Grund, T.U.; Koskinen, J.H. Residential segregation and 'ethnic flight' vs. 'ethnic avoidance' in Sweden. Eur. Sociol. Rev. 2018, 34, 268-285. [CrossRef]

50. Welin, L.; Bildsten, L. The housing market in Sweden: A political-historical perspective. In Proceedings of the 9th Nordic Conference on Construction Economics and Organization, at Chalmers University of Technology, Göteborg, Sweden, 13-14 June 2017.

51. Lind, H. The Swedish housing market from a low income perspective. Crit. Hous. Anal. 2017, 4, 150-160. [CrossRef]

52. Grander, M. The inbetweeners of the housing markets-Young adults facing housing inequality in Malmö, Sweden. Hous. Stud. 2021, 1-18. Available online: https:/ / www.tandfonline.com/doi/full/10.1080/02673037.2021.1893278 (accessed on 16 June 2021). [CrossRef]

53. Tang, C.P.Y.; Oxley, M.; Mekic, D. Meeting commercial and social goals: Institutional investment in the housing association sector. Hous. Stud. 2016, 32, 411-427. [CrossRef]

54. Fields, D.; Uffer, S. The financialisation of rental housing: A comparative analysis of New York City and Berlin. Urban. Stud. 2014, 53, 1486-1502. [CrossRef]

55. Heimersson, A. Internationella Företag Köper upp Fastigheter i Miljonprogrammen, in Dagens Arena. 2018. Available online: https:/ / www.dagensarena.se/innehall/internationella-foretag-koper-upp-fastigheter-miljonprogrammen/ (accessed on 30 April 2021).

56. Svenska Hyreshus Köps upp av Utländska Köpare, in Dagens Nyheter. 2019. Available online: https://www.dn.se/ekonomi/ svenska-hyreshus-kops-upp-av-utlandska-kopare/ (accessed on 30 April 2021).

57. Olsén, P.; Björkvald, M.; Hyresgästföreningen. Konceptrenoveringens Konsekvenser: Ekonomiska och Socioekonomiska Effekter. 2019. Available online: https://resources.mynewsdesk.com/image/upload/rsckypa8tfkrmxdww8ym.pdf (accessed on 30 April 2021).

58. Lind, H. The effect of rent regulations and contract structure on renovation: A theoretical analysis of the swedish system. Hous. Theory Soc. 2015, 32, 389-406. [CrossRef]

59. Energimyndigheten. Stora Vinster med Energieffektiv Renovering av Miljonprogrammen. 2015. Available online: http://www. energimyndigheten.se/arkiv-for-resultat/Resultat/stora-vinster-med-energieffektiv-renovering-av-miljonprogrammen/ (accessed on 10 June 2020).

60. Mjörnell, K.; Femenías, P.; Annadotter, K. Renovation strategies for multi-residential buildings from the record years in SwedenProfit-Driven or socioeconomically responsible? Sustainability 2019, 11, 6988. [CrossRef]

61. Lind, H.; Annadotter, K.; Björk, F.; Högberg, L.; Klintberg, T.A. Sustainable renovation strategy in the swedish million homes programme: A case study. Sustainability 2016, 8, 388. [CrossRef]

62. Stenberg, J. Dilemmas associated with tenant participation in renovation of housing in marginalized areas may lead to system change. Cogent Soc. Sci. 2018, 4, 1528710. [CrossRef]

63. Stenberg, J.; Thuvander, L.; Femenías, P. Linking social and environmental aspects: A multidimensional evaluation of refurbishment projects. Local Environ. 2009, 14, 541-556. [CrossRef]

64. Lind, H. Pricing principles and incentives for energy efficiency investments in multi-family rental housing: The case of Sweden. Energy Policy 2012, 49, 528-530. [CrossRef]

65. Baeten, G.; Westin, S.; Pull, E.; Molina, I. Pressure and violence: Housing renovation and displacement in Sweden. Environ. Plan. A Econ. Space 2016, 49, 631-651. [CrossRef]

66. Molina, I.; Westin, S. Renoviction-Even in Sweden? Four Case Studies on the Regeneration of Public Housing Estates, in AAG Annual Meeting of the Association of American Geographers; New York. 2012. Available online: https://www.diva-portal.org/ smash/record.jsf?pid=diva2\%3A526369\&dswid=5191 (accessed on 30 April 2021).

67. Bouzarovski, S.; Frankowski, J.; Herrero, S.T. Low-Carbon gentrification: When climate change encounters residential displacement. Int. J. Urban. Reg. Res. 2018, 42, 845-863. [CrossRef]

68. Gould, K.A.; Lewis, T.L. Green Gentrification: Urban Sustainability and the Struggle for Environmental Justice; Routledge Equity, Justice and the Sustainable City Series; Taylor \& Francis: Abingdon, UK, 2016.

69. Marcuse, P. Gentrification, abandonment, and displacement: Connections, causes, and policy responses in New York city. Urban Law Annual. J. Urban Contemp. Law 1985, 28, 195-240.

70. Wetterberg, K. Hyresgästinflytande vid Förbättrings-och Ändringsarbeten: En Lucka i Besittningsskyddet? Master's Thesis, Uppsala University, Uppsala, Sweden, 2016; p. 55. Available online: http://uu.diva-portal.org/smash/record.jsf?dswid=5191\&facesredirect $=$ true\&aq2 $=\% 5 \mathrm{~B} \% 5 \mathrm{~B} \% 5 \mathrm{D} \% 5 \mathrm{D} \& \mathrm{af}=\% 5 \mathrm{~B} \% 5 \mathrm{D} \&$ searchType=LIST_LATEST\&sortOrder2=title_sort_asc\&language=sv\& pid=diva2\%3A1044334\&aq=\%5B \%5B \%5D \%5D\&sf=all\&aqe=\%5B \%5D\&sortOrder=author_sort_asc\&onlyFullText=false\& noOfRows $=50$ (accessed on 30 April 2021).

71. Polanska, D.; Richard, A. Narratives of a fractured trust in the Swedish model: Tenants' emotions of renovation. Cult. Unbound: J. Curr. Cult. Res. 2019, 11, 141-164. [CrossRef]

72. Palm, J.; Reindl, K.; Ambrose, A. Understanding tenants' responses to energy efficiency renovations in public housing in Sweden: From the resigned to the demanding. Energy Rep. 2020, 6, 2619-2626. [CrossRef]

73. Bengtsson, B.; Bohman, H. Tenant voice-As strong as it gets: Exit, voice and loyalty in housing renovation. Hous. Theory Soc. 2021, 38, 365-380. [CrossRef] 
74. Henning, A. Indoor Climate Agreements in Energy-Efficiency and Renovation Projects-A Question of Justice? In Proceedings of the EuroSun2018, Rapperswil, Switzerland, 10-13 September 2018; Haberle, A., Ed.; pp. 1694-1703.

75. Savvidou, G.; Nykvist, B. Heat demand in the Swedish residential building stock-Pathways on demand reduction potential based on socio-technical analysis. Energy Policy 2020, 144, 111679. [CrossRef]

76. Boverket, Underlag till Den Andra Nationella Strategin för Energieffektiviserande Renovering. 2016. Available online: https:/ / www.boverket.se/sv/om-boverket/publicerat-av-boverket/publikationer/2016/underlag-till-den-andra-nationellastrategin-for-energieffektiviserande-renovering/ (accessed on 30 April 2021).

77. Mjörnell, K.; Boss, A.; Lindahl, M.; Molnar, S. A tool to evaluate different renovation alternatives with regard to sustainability. Sustainability 2014, 6, 4227-4245. [CrossRef]

78. Hiller, C. What have Residents Got to Do with It? Variations in Energy Use and Energy-Related Behaviours in Single-Family Houses in Byggnadsfysik LTH, Lunds Tekniska Högskola; Lund University: Lund, Sweden, 2020.

79. Pullinger, M.; Browne, A.; Anderson, B.; Medd, W. Patterns of Water: The Water Related Practices of Households in Southern England, and Their Influence on Water Consumption and Demand Management. 2013. Available online: https://eprints.soton. ac.uk/359514/ (accessed on 30 April 2021).

80. Ástmarsson, B.; Jensen, P.A.; Maslesa, E. Sustainable renovation of residential buildings and the landlord/tenant dilemma. Energy Policy 2013, 63, 355-362. [CrossRef]

81. Von Platten, J.; Mangold, M.; Mjörnell, K. Energy inequality as a risk in socio-technical energy transitions: The Swedish case of individual metering and billing of energy for heating. IOP Conf. Series Earth Environ. Sci. 2020, 588, 032015. [CrossRef]

82. Lag (2014:267) om Energimätning i Byggnader. Available online: https://www.riksdagen.se/sv/dokument-lagar/dokument/ svensk-forfattningssamling/lag-2014267-om-energimatning-i-byggnader_sfs-2014-267 (accessed on 16 June 2021).

83. Zhang, Y.; Bai, X.; Mills, F.P.; Pezzey, J. Rethinking the role of occupant behavior in building energy performance: A review. Energy Build. 2018, 172, 279-294. [CrossRef]

84. Köhler, H. Individual metering and debiting (IMD) in Sweden: A qualitative long-term follow-up study of householders' water-use routines. Energy Policy 2017, 108, 344-354. [CrossRef]

85. Mangold, M.; Morrison, G.; Harder, R.; Hagbert, P.; Rauch, S.; Morrison, G. The transformative effect of the introduction of water volumetric billing in a disadvantaged housing area in Sweden. Hydrol. Res. 2014, 16, 973-990. [CrossRef]

86. Mangold, M.; Wallbaum, H.; Österbring, M. A review of Swedish residential building stock research. Int. J. Environ. Sustain. 2015, 10, 1-17. [CrossRef]

87. Sorrell, S.; Dimitropoulos, J.; Sommerville, M. Empirical estimates of the direct rebound effect: A review. Energy Policy 2009, 37, 1356-1371. [CrossRef]

88. Höjer, M.; Mjörnell, K. Measures and steps for more efficient use of buildings. Sustainability 2018, 10, 1949. [CrossRef]

89. Francart, N.; Höjer, M.; Mjörnell, K.; Orahim, A.S.; Von Platten, J.; Malmqvist, T. Sharing indoor space: Stakeholders' perspectives and energy metrics. Build. Cities 2020, 1, 70-85. [CrossRef]

90. The Hague: Ministry of the Interior and Kingdom Relations, Housing Statistics in the European Union 2010; OTB Research Institute for the Built Environment, Delft University of Technology: Delft, The Netherlands, 2010.

91. SCB. Var Femte Person Född Utanför Europa är Trångbodd. 2018. Available online: https://www.scb.se/hitta-statistik/artiklar/ 2018/var-femte-person-fodd-utanfor-europa-ar-trangbodd/ (accessed on 10 June 2020).

92. Ivanova, D.; Büchs, M. Household sharing for carbon and energy reductions: The case of EU countries. Energies 2020, 13, 1909. [CrossRef]

93. Keilman, N. The threat of small households. Nature 2003, 421, 489-490. [CrossRef] [PubMed]

94. Sovacool, B.; Dworkin, M.H. Energy justice: Conceptual insights and practical applications. Appl. Energy 2015, 142, 435-444. [CrossRef]

95. Beauchamp, T.; Childress, J. Principles of biomedical ethics: Marking its fortieth anniversary. Am. J. Bioeth. 2019, 19, 9-12. [CrossRef] [PubMed]

96. Miller, D. Justice, in The Stanford Encyclopedia of Philosophy; Zalta, E.N., Ed.; Metaphysics Research Lab, Stanford University: Stanford, CA, USA, 2017.

97. Nozick, R. Anarchy, State, and Utopia; Basic Books: New York, NY, USA, 1974; Volume 5038.

98. Daniels, N.; Sabin, J. Setting Limits Fairly: Can We Learn to Share Medical Resources? Oxford University Press: Oxford, UK, 2002.

99. Dodd, N.; Habermas, J.; White, S.K. Between facts and norms: Contributions to a discourse theory of law and democracy. Br. J. Sociol. 1997, 48, 329. [CrossRef]

100. Hansson, S.O. How to perform an ethical Risk Analysis (eRA). Risk Anal. 2018, 38, 1820-1829. [CrossRef]

101. Frankfurt, H. Equality as a moral ideal. Ethics 1987, 98, 21-43. [CrossRef]

102. Herlitz, A. The indispensability of sufficientarianism. Crit. Rev. Int. Soc. Political Philos. 2019, 22, 929-942. [CrossRef]

103. Temkin, L.S. Inequality; Oxford University Press: Oxford, UK, 1993.

104. Persson, I. A defence of extreme egalitarianism. In Egalitarianism: New Essays on the Nature and Value of Equality; Clarendon Press: Oxford, UK, 2007; pp. 83-98.

105. Parfit, D. Equality or Priority? The Lindley Lecture, University of Kansas, 21 November 1991; University of Kansas: Lawrence, KS, USA, 1991.

106. Adler, M.D.; Holtug, N. Prioritarianism: A response to critics. Politi-Philos. Econ. 2019, 18, 101-144. [CrossRef] 
107. Sidgwick, H. The Methods of Ethics; Good Press: Glasgow, UK, 1907.

108. Tännsjö, T. Hedonistic Utilitarianism; Edinburgh University Press: Edinburgh, UK, 1998.

109. Sher, G. Desert; Princeton University Press: Princeton, NJ, USA, 1989; Volume 3.

110. Kagan, S. The Geometry of Desert; Oxford University Press: Oxford, UK, 2014.

111. Knight, C. Luck Egalitarianism: Equality, Responsibility, and Justice; Edinburgh University Press: Edinburgh, UK, 2009.

112. Honneth, A. Recognition and justice: Outline of a plural theory of justice. Acta Sociol. 2004, 47, 351-364. [CrossRef]

113. Sen, A. Equality of what? Tann. Lect. Hum. Values 1980, 1, 197-220.

114. Cohen, G.A. On the currency of egalitarian justice. Ethics 1989, 99, 906-944. [CrossRef]

115. Brülde, B. The Human Good; University of Gothenburg: Gothenburg, Sweden, 1998.

116. Crisp, R. Well-Being. In The Stanford Encyclopedia of Philosophy; Zalta, E.N., Ed.; 2017. Available online: https://plato.stanford. edu/archives/fall2017/entries/well-being/ (accessed on 30 April 2021).

117. Hurka, T. Perfectionism; Oxford University Press on Demand: Oxford, UK, 1993.

118. Watson, D.; Clark, L.A.; Tellegen, A. Development and validation of brief measures of positive and negative affect: The PANAS scales. J. Personal. Soc. Psychol. 1988, 54, 1063. [CrossRef]

119. Diener, E.; Emmons, R.A.; Larsen, R.J.; Griffin, S. The satisfaction with life scale. J. Personal. Assess. 1985, 49, 71-75. [CrossRef]

120. Waterman, A.S.; Schwartz, S.J.; Zamboanga, B.L.; Ravert, R.D.; Williams, M.K.; Agocha, V.B.; Kim, S.Y.; Donnellan, M.B. The questionnaire for Eudaimonic well-being: Psychometric properties, demographic comparisons, and evidence of validity. J. Posit. Psychol. 2010, 5, 41-61. [CrossRef] [PubMed]

121. Sen, A. Inequality Reexamined; Oxford University Press: Oxford, UK, 1992.

122. Nussbaum, M.C. Creating capabilities: The human development approach and its implementation. Hypatia $2008,24,211-215$. [CrossRef]

123. Anand, P.; Hunter, G.; Carter, I.; Dowding, K.; Guala, F.; Van Hees, M. The development of capability indicators. J. Hum. Dev. Capab. 2009, 10, 125-152. [CrossRef]

124. Rawls, J. A Theory of Justice; Belknap Press of Harvard University Press: Cambridge, MA, USA, 1971.

125. Robeyns, I. Assessing global poverty and inequality: Income, resources, and capabilities. Metaphilosophy 2005, 36, 30-49. [CrossRef]

126. de Fine Licht, K. Responsibility and Health: Explanation-Based Perspectives; University of Gothenburg: Gothenburg, Sweden, 2014.

127. Ross, W. The Right and the Good; Oxford University Press: Oxford, UK, 1930.

128. Herlitz, A.; Sadek, K. Social choice, nondeterminacy, and public reasoning. Res. Philos. 2021, 98, 377-401. [CrossRef]

129. Nord, E. Cost-Value Analysis in Health Care: Making Sense out of QALYs; Cambridge University Press: Cambridge, UK, 1999.

130. Brandstedt, E.; Brülde, B. Towards a theory of pure procedural climate justice. J. Appl. Philos. 2018, 36, 785-799. [CrossRef] 